\title{
CARBOHYDRATE METABOLISM IN ADDISON'S DISEASE ${ }^{1}$
}

\author{
By GEORGE W. THORN, GEORGE F. KOEPF, ROGER A. LEWIS,2 AND \\ ELIZABETH F. OLSEN \\ (From the Chemical Division, Medical Clinic, The Johns Hopkins University \\ and Hospital, Baltimore)
}

(Received for publication July 15, 1940)

Our understanding of the nature of the disordered carbohydrate metabolism in Addison's disease has advanced little since the original demonstration by Porges in 1910 (1) of the frequent occurrence of hypoglycemic reactions and the studies of Eppinger, Falta and Rudinger in which an increase in glucose tolerance was noted (2). Subsequently, however, it was shown that patients with Addison's disease developed marked symptoms of hypoglycemia following the administration of small doses of insulin (3) and failed to show a rise of blood sugar as great as normal subjects following the injection of a standard dose of epinephrin (4).

Recently Long, Katzin and Fry (5) reported in detail their studies relating to the effect of adrenal cortical hormone on the carbohydrate metabolism of experimental animals. From their own studies, as well as those of others, these authors concluded that "the administration of cortical extract apparently decreases the proportion of glucose oxidized while there is an increased proportion deposited as liver glycogen. ... It is suggested that one of the properties of the cortical hormone is a stimulation of protein catabolism and that the increased carbohydrate levels, nitrogen and potassium excretion following its injection into animals is an expression of this effect."

A study of carbohydrate metabolism in untreated patients with Addison's disease is difficult because of the poor clinical condition of these patients. In the present study we have had the good fortune to be able to complete carefully controlled metabolic studies on a limited number of untreated patients and on a larger number of patients who were maintained in good condition by

1 This study was aided by a grant from the Committee on Research in Endocrinology, National Research Council.

2 John D. Archbold, Fellow in Medicine. means of synthetic desoxycorticosterone acetate therapy. ${ }^{3}$

\section{METHODS}

Before these studies were undertaken, normal subjects and patients with Addison's disease were maintained for a period of 1 to 2 weeks on a standard diet of adequate caloric intake. The ratio of carbohydrate: protein: fat was kept constant. In most instances patients received 5.0 grams of carbohydrate, 1.3 grams of protein and 1.5 grams of fat per $\mathrm{kgm}$. of body weight.

\section{Respiratory metabolism}

During a preliminary period of 1 to 2 weeks, both the normal subjects and patients were trained for respiratory metabolic studies. Expired air was collected for 10-minute periods in a modified Baily gasometer and samples were analyzed in duplicate for carbon dioxide and oxygen by means of a Haldane-Henderson gas analyzer. Differential derivation of calories was made with the aid of Lusk's table (6). In addition to determining the standard metabolism after a 15-hour fast, the respiratory metabolism, blood sugar (7) and urinary nitrogen (Kjeldahl) were determined throughout the day at 2-hour intervals during a total fasting period of 22 hours. These determinations were repeated following the injection of adrenal cortical extract (Wilson, $50 \mathrm{cc}$.).4 The respiratory quotient, blood sugar and urinary nitrogen excretion were determined at hourly intervals following the intravenous administration of glucose before and after treatment with adrenal cortical extract (50 cc.), desoxycorticosterone acetate $\left(30 \mathrm{mgm}\right.$.), corticosterone $(85 \mathrm{mgm}),.{ }^{5}$ and 17-hydroxy-11-dehydrocorticosterone (33 $\mathrm{mgm}$.) (Kendall's Compound E). ${ }^{5}$

\section{Standard intravenous glucose tolerance test}

A test was adopted in which 0.5 gram of glucose per $\mathrm{kgm}$. of body weight was injected intravenously as a 20

3 The synthetic desoxycorticosterone acetate used in this study was provided through the courtesy of Doctor E. Oppenheimer, of the Ciba Pharmaceutical Products, Inc., Summit, N. J.

- The adrenal cortical extract used in this study was supplied by Doctor David Klein of the Wilson Company, Chicago, Ill.

$5 \mathrm{We}$ are indebted to Doctor E. C. Kendall of the Mayo Clinic, Rochester, Minn., for the crystalline corticosterone and 17-hydroxy-11-dehydrocorticosterone (Compound $\mathrm{E})$. 
per cent solution in distilled water. The flow was adjusted so that the infusion was completed in 30 minutes. This rate of glucose administration $(0.5 \mathrm{gram}$ per $\mathrm{kgm}$. per $1 / 2$ hour) approximated the maximum rate of intestinal absorption of glucose and hence provided an intravenous glucose test which was within physiological limits. Capillary blood for sugar determinations was taken in the fasting state and at 30-minute intervals during a 4-hour period following the glucose infusion. Urine specimens were collected at appropriate intervals and analyzed for sugar.

\section{Oral glucose tolerance test}

A solution of glucose, 1.75 grams per $\mathrm{kgm}$. of body weight, was given. Capillary blood for sugar determinations was taken during the fasting state and 30,60 , 120 and 180 minutes after the ingestion of glucose.

\section{Epinephrin test}

Epinephrin, $0.007 \mathrm{mgm}$. per $\mathrm{kgm}$. of body weight, was injected subcutaneously. The site of the injection was massaged vigorously for a period of 2 minutes. Capillary blood for sugar determinations was taken during the fasting state and $15,30,60$ and 90 minutes after the injection of epinephrin.

\section{OBSERVATIONS}

\section{Increased appetite for carbohydrate}

It is of interest to note that many patients with Addison's disease had formed the habit of supplementing their regular diet with intermediate nourishment of foods containing readily available carbohydrate (Patient E. L., see protocol). In this respect there is a parallel to the increased appetite for salt and salty foods which has been noted clinically by many observers, and confirmed experimentally by the studies of Richter and Eckert on adrenalectomized rats (8).

\section{Fasting blood glucose}

The fasting blood glucose level of untreated patients with Addison's disease was observed to be in the low-normal range in most instances. In a group of 20 patients the average blood glucose value $^{\circ}$ (108 determinations) was observed to be $80 \mathrm{mgm}$. per $100 \mathrm{cc}$. before treatment. Prolonged treatment with desoxycorticosterone acetate did not affect the fasting blood glucose level since the average value observed during treatment was also

- All blood sugar values determined by the modified micromethod of Folin and Malmros are arbitrarily referred to in this study as "blood glucose values."
80 mgm. per 100 cc. (166 determinations). These observations confirm earlier studies $(9,10)$.

Treatment with adrenal cortical extract (Wilson, 4 to $10 \mathrm{cc}$. daily, injected subcutaneously) was associated with an appreciable rise in the average fasting blood glucose level (Table I).

TABLE I

Effect of adrenal cortical hormone therapy on fasting blood glucose

(Addison's disease)

\begin{tabular}{|c|c|c|c|c|c|c|}
\hline & \multicolumn{6}{|c|}{ Fasting blood gluoose (mom. per 100 cc.) } \\
\hline & $\begin{array}{l}\text { Before } \\
\text { troat- } \\
\text { ment }\end{array}$ & $\begin{array}{l}\text { Desoxy- } \\
\text { oortioos- } \\
\text { terone } \\
\text { acetate" }\end{array}$ & $\begin{array}{l}\text { Adrenal } \\
\text { cortioal } \\
\text { ertraot } \\
\text { (injected) }\end{array}$ & $\begin{array}{l}\text { Adrenal } \\
\text { cortioal } \\
\text { extraot } \\
\text { (oral) }\end{array}$ & $\begin{array}{c}\text { Cortioos- } \\
\text { terone } \\
\text { (in- } \\
\text { jected) }\end{array}$ & $\begin{array}{l}\text { 17-hydrozy- } \\
11 \text {-dehydro- } \\
\text { oortioos- } \\
\text { terone } \\
\text { (injeoted) }\end{array}$ \\
\hline & & $\begin{array}{c}\text { 3-20 mgm. } \\
\text { daily }\end{array}$ & $\begin{array}{c}4-1000 . \\
\text { daily }\end{array}$ & $\begin{array}{c}8-1200 . \\
\text { daily }\end{array}$ & 85 mgm. & 33 mgm. \\
\hline $\begin{array}{l}5 \text { pationts..... } \\
\text { (Number of do- } \\
\text { tominations). }\end{array}$ & $\begin{array}{l}76 \\
(43)\end{array}$ & $\begin{array}{c}77 \\
(60)\end{array}$ & $\begin{array}{c}81 \\
(20)\end{array}$ & $\begin{array}{c}83 \\
(30)\end{array}$ & & \\
\hline $\begin{array}{l}\text { Patient E. L... } \\
\text { Range......... }\end{array}$ & $\begin{array}{c}75 \\
(68-81)\end{array}$ & $\begin{array}{c}75 \\
(72-81)\end{array}$ & $\begin{array}{l}84 \\
90 t\end{array}$ & & 99 & 85 \\
\hline
\end{tabular}

* Includes values observed during treatment with either daily intramuscular injection of a solution of hormone in oil, or subcutaneously implanted pellets of crystalline desoxycorticosterone acetate.

† Massive dose, 50-70 cc., during a 24-hour period.

The oral administration of larger quantities of adrenal cortical extract in glycerol solution ( 8 to 12 cc. daily, 1 cc. representing 50 grams of adrenal gland) was likewise associated with a rise in the average value for fasting blood glucose. Treatment with large quantities of adrenal cortical extract (Wilson, 20 to $50 \mathrm{cc}$. daily, injected subcutaneously and intravenously), corticosterone (85 mgm.) and 17-hydroxy-11-dehydrocorticosterone (33 $\mathrm{mgm}$.) in oil, injected intramuscularly in divided doses, was followed by a much greater elevation in fasting blood glucose level (Patient E. L., Table I).

The efficacy of treatment with adrenal cortical extract ( 50 to $70 \mathrm{cc}$.) in preventing the gradual fall in blood glucose during a prolonged fast is illustrated in Figure 1. The rise in blood glucose which reached its maximum 6 to 8 hours after injection of extract did not appear to be due to traces of epinephrin which may have been present in the extract, since there was no immediate rise in blood glucose as might have been anticipated following an injection of epinephrin. 


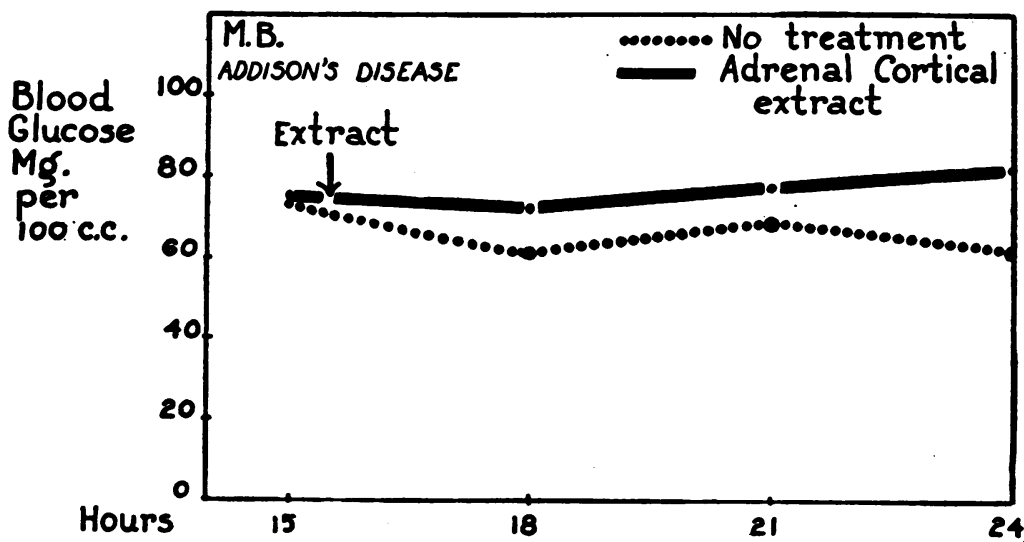

Fig. 1. Effect of Adrenal Cortical Extract on Blood Glucose Level (Prolonged Fast)

\section{Oral glucose tolerance}

The striking intolerance of patients with Addison's disease to the oral administration of glucose is well known (11). Not infrequently an adrenal crisis has been precepitated by this test.

A comparison between the blood glucose values of 8 control subjects and 4 untreated patients with Addison's disease following the oral administration of glucose, is shown in Figure 2. The lownormal initial fasting sugar level, the "flat-type" of glucose curve, and the striking hypoglycemia which was frequently noted 2 to 3 hours following the administration of glucose are of particular significance in the response of patients with Addison's disease. At the time of initial examination, approximately 75 per cent of a group of 30 patients with Addison's disease were found to have an abnormal oral glucose tolerance curve.

The symptoms of pylorospasm which so frequently followed the oral administration of glucose to these patients suggest that the apparent increase in glucose tolerance (flat-type of curve) was in a large measure due to an abnormality in the intestinal absorption of glucose. This was confirmed by the normal height to which the blood glucose level rose following the intravenous ad-

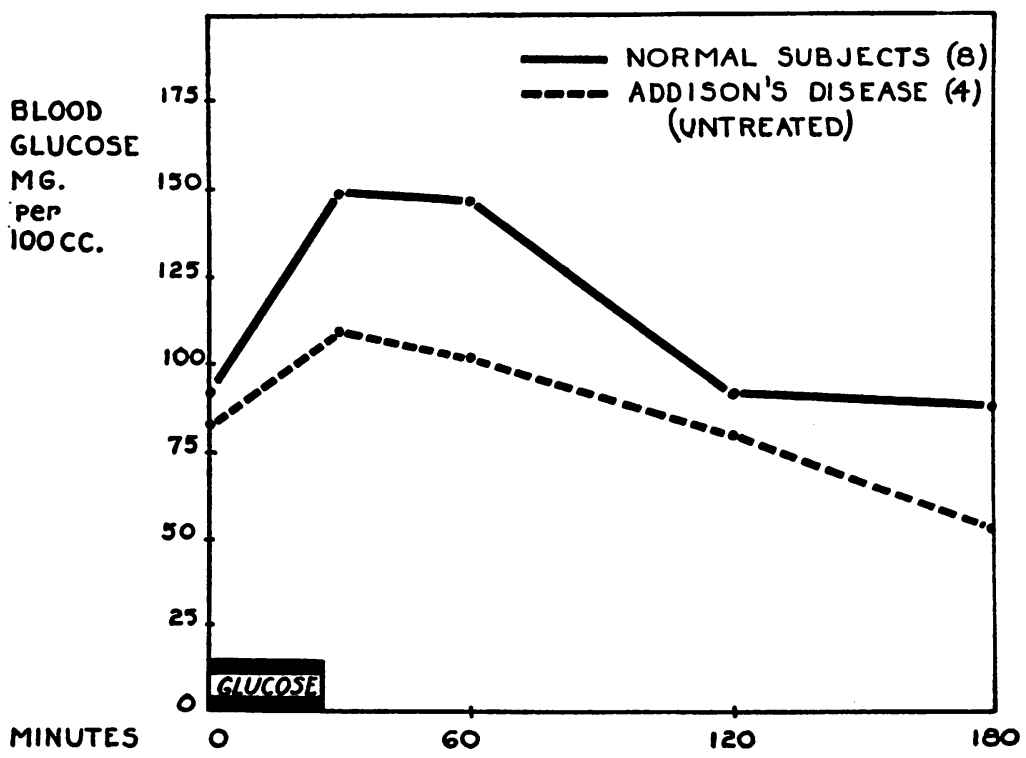

Fig. 2. Oral Glucose Tolerance Test 


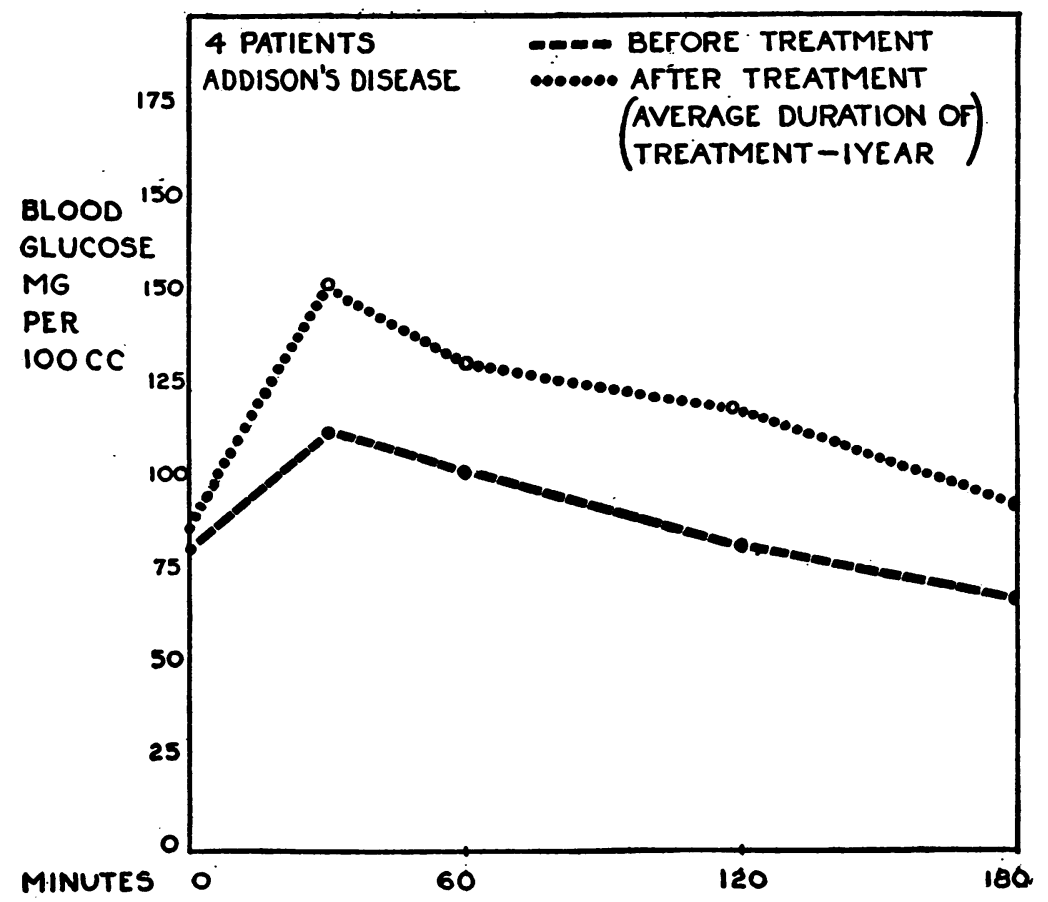

Fig. 3. Oral Glucose Tolerance Test. The Effect of DEsOXYCorticosterone TreatMent

ministration of a standard dose of glucose (see Figure 5).

Following prolonged treatment (1 year or more) with desoxycorticosterone acetate, we observed a marked change in the oral glucose tolerance curve in 4 patients (Figure 3 ). The clinical condition of these patients was markedly improved at the time the second glucose curve was determined. It would seem likely that the change in the glucose curve was due primarily to improved absorption of glucose from the intestinal tract and not to a marked or specific effect of desoxycorticosterone acetate on the internal metabolism of glucose, inasmuch as desoxycortico-

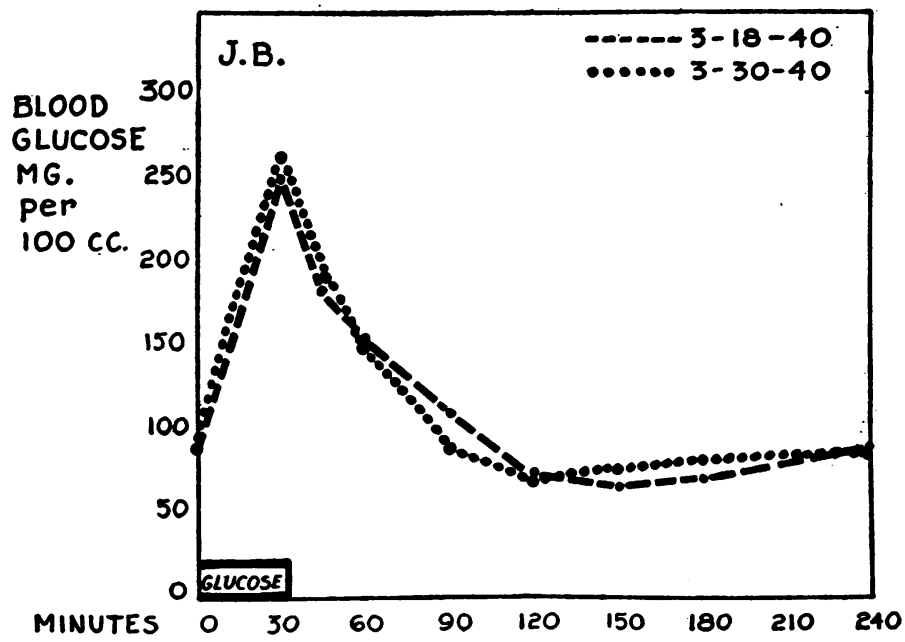

Fig. 4. Intravenous Glucose Tolerance Test Norual Subject 


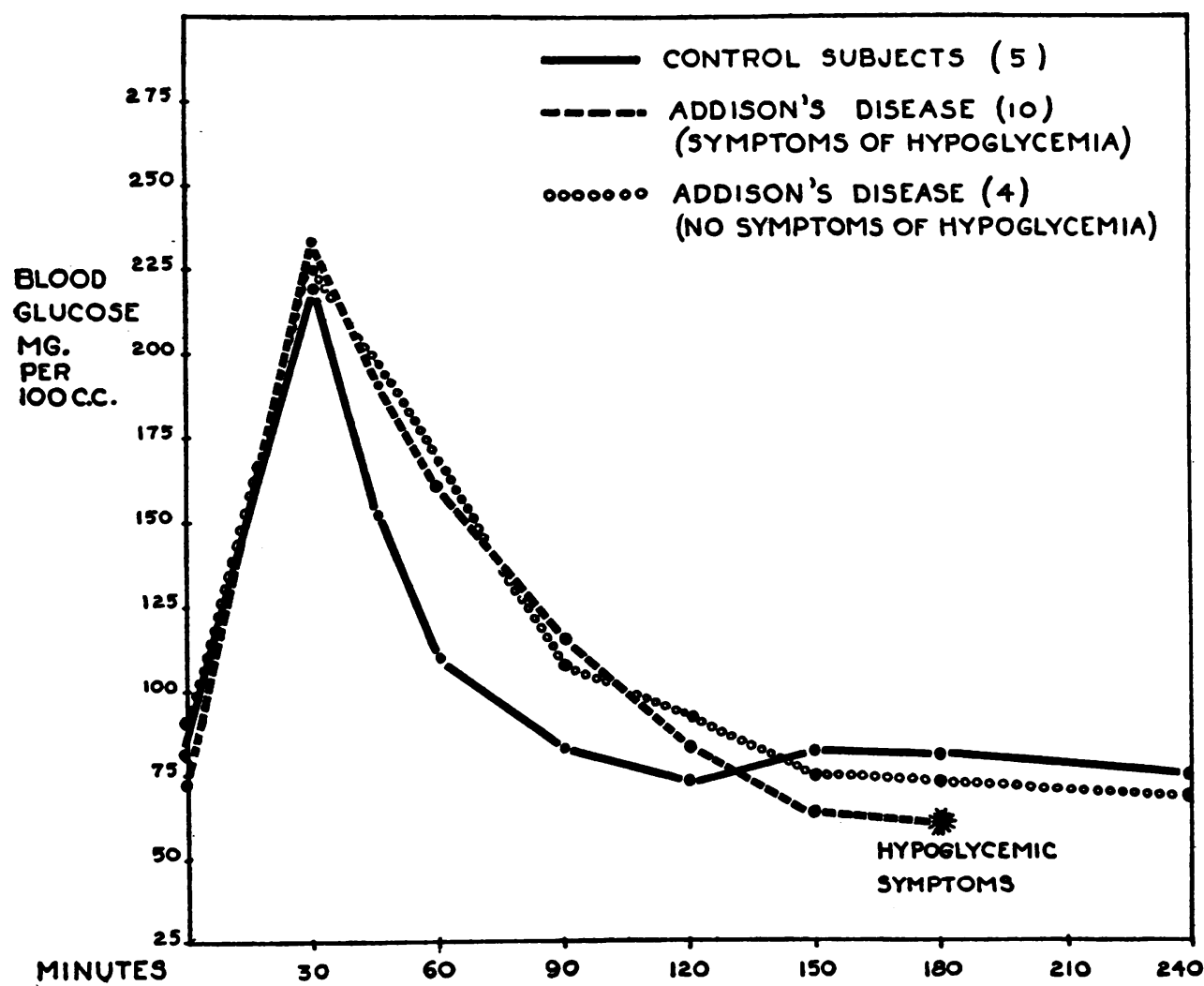

Fig. 5. Intravenous Glucose Tolerance Test in Patients with Addison's Disease

sterone acetate therapy had no demonstrable effect on the blood glucose curve following the intravenous administration of glucose.

\section{Intravenous glucose tolerance}

In order to eliminate the obvious disadvantages of glucose administered orally, we used a standard intravenous glucose tolerance test (see methods). One consideration seemed essential, viz., that the rate of glucose solution introduced intravenously should not exceed the maximum rate of intestinal absorption of glucose, if physiological studies were to be made. Experience now indicates that, under constant conditions, the blood glucose curve following the intravenous administration of 0.5 gram of glucose per $\mathrm{kgm}$. of body weight during a 30-minute period is constant for a given individual (Figure 4).

Patients with Addison's disease frequently developed marked symptoms of hypoglycemia 2 to 3 hours after the administration of glucose intravenously (Table II). In some patients coma and vasomotor collapse occurred and additional glu-
TABLE II

Intravenous glucose tolerance curve

\begin{tabular}{|c|c|c|c|c|c|c|c|c|c|c|c|}
\hline \multirow{3}{*}{$\begin{array}{c}\text { Pa- } \\
\text { tient }\end{array}$} & \multirow{3}{*}{ Sex } & \multirow{3}{*}{ Age } & \multicolumn{9}{|c|}{ PATIENTS WITH ADDISON'S DISEASE } \\
\hline & & & \multicolumn{9}{|c|}{ Blood glucose (mgm. per $100 \mathrm{cc}$.) } \\
\hline & & & $\begin{array}{l}\text { Fast- } \\
\text { ing }\end{array}$ & $\begin{array}{l}30 \\
\text { min- } \\
\text { utes }\end{array}$ & $\begin{array}{c}45 \\
\text { min- } \\
\text { utes }\end{array}$ & $\begin{array}{l}60 \\
\text { min- } \\
\text { utes }\end{array}$ & $\begin{array}{c}90 \\
\text { min- } \\
\text { utes }\end{array}$ & $\begin{array}{l}120 \\
\text { min- } \\
\text { utes }\end{array}$ & $\begin{array}{l}150 \\
\text { min- } \\
\text { utes }\end{array}$ & $\begin{array}{l}180 \\
\min - \\
\text { utes }\end{array}$ & $\begin{array}{l}240 \\
\text { min- } \\
\text { utes }\end{array}$ \\
\hline $\begin{array}{l}\text { F. H. } \\
\text { Y. } \\
\text { S. W. } \\
\text { J.P. } \\
\text { M. } \\
\text { O. } \\
\text { O. } \\
\text { E. L. } \\
\text { A. H. } \\
\text { O. } \\
\text { B. W. } \\
\text { A. S. } \\
\text { S. P. } \\
\text { A. H. } \\
\text { H. H. }\end{array}$ & $\begin{array}{l}\mathbf{M} \\
\mathbf{F} \\
\mathbf{F} \\
\mathbf{M} \\
\mathbf{F} \\
\mathbf{M} \\
\mathbf{F} \\
\mathbf{M} \\
\mathbf{M} \\
\mathbf{M} \\
\mathbf{M} \\
\mathbf{M} \\
\mathbf{F} \\
\mathbf{M}\end{array}$ & $\begin{array}{l}21 \\
39 \\
55 \\
21 \\
31 \\
43 \\
51 \\
39 \\
62 \\
26 \\
33 \\
27 \\
20 \\
38\end{array}$ & $\begin{array}{r}77 \\
79 \\
111 \\
79 \\
78 \\
78 \\
76 \\
89 \\
81 \\
86 \\
78 \\
80 \\
78 \\
99\end{array}$ & \begin{tabular}{|l}
210 \\
225 \\
426 \\
270 \\
250 \\
241 \\
235 \\
241 \\
264 \\
200 \\
206 \\
222 \\
254
\end{tabular} & $\begin{array}{l}182 \\
235 \\
202 \\
182 \\
183 \\
182 \\
215 \\
164 \\
194 \\
225\end{array}$ & \begin{tabular}{|l}
163 \\
177 \\
171 \\
192 \\
135 \\
140 \\
153 \\
140 \\
149 \\
196 \\
131 \\
156 \\
164 \\
153
\end{tabular} & \begin{tabular}{|l|}
123 \\
120 \\
100 \\
163 \\
77 \\
100 \\
103 \\
113 \\
118 \\
142 \\
105 \\
105 \\
131 \\
112 \\
\end{tabular} & $\begin{array}{r}86 \\
118 \\
77 \\
99 \\
56 \\
74 \\
77 \\
72 \\
90 \\
105 \\
84 \\
80 \\
97 \\
104\end{array}$ & $\begin{array}{l}65 \\
84 \\
69 * \\
75 \\
48^{*} \\
52 \\
61 \\
61^{*} \\
76 \\
86 \\
68 \\
68 \\
70 \\
78\end{array}$ & $\begin{array}{l}50 \\
66 \\
62^{*} \\
61^{*} \\
50^{*} \\
68 \\
68 \\
69 \\
62 \\
60 \\
60 \\
78\end{array}$ & $\begin{array}{l}62 \\
69 \\
77 \\
72 \\
64 \\
80\end{array}$ \\
\hline
\end{tabular}

NORMAL SUBJECTS

\begin{tabular}{l|l|l|l|l|l|r|r|r|r|r|r}
\hline F. A. & M & 23 & 81 & 282 & 204 & 164 & 88 & 67 & 69 & 82 & 106 \\
A. K. & M & 23 & 84 & & 194 & & 91 & 78 & 71 & 76 & 84 \\
C. D. & M & 26 & 89 & 220 & 123 & 70 & 55 & 78 & 80 & 84 & 87 \\
R. L. & M & 28 & 95 & 290 & 202 & 164 & 106 & 75 & 73 & 64 & 68 \\
S. A. & M & 25 & $\mathbf{8 7}$ & $\mathbf{2 2 0}$ & 155 & 110 & 81 & 76 & 83 & 81 & 78 \\
\hline
\end{tabular}

* Hypoglycemic reaction. 


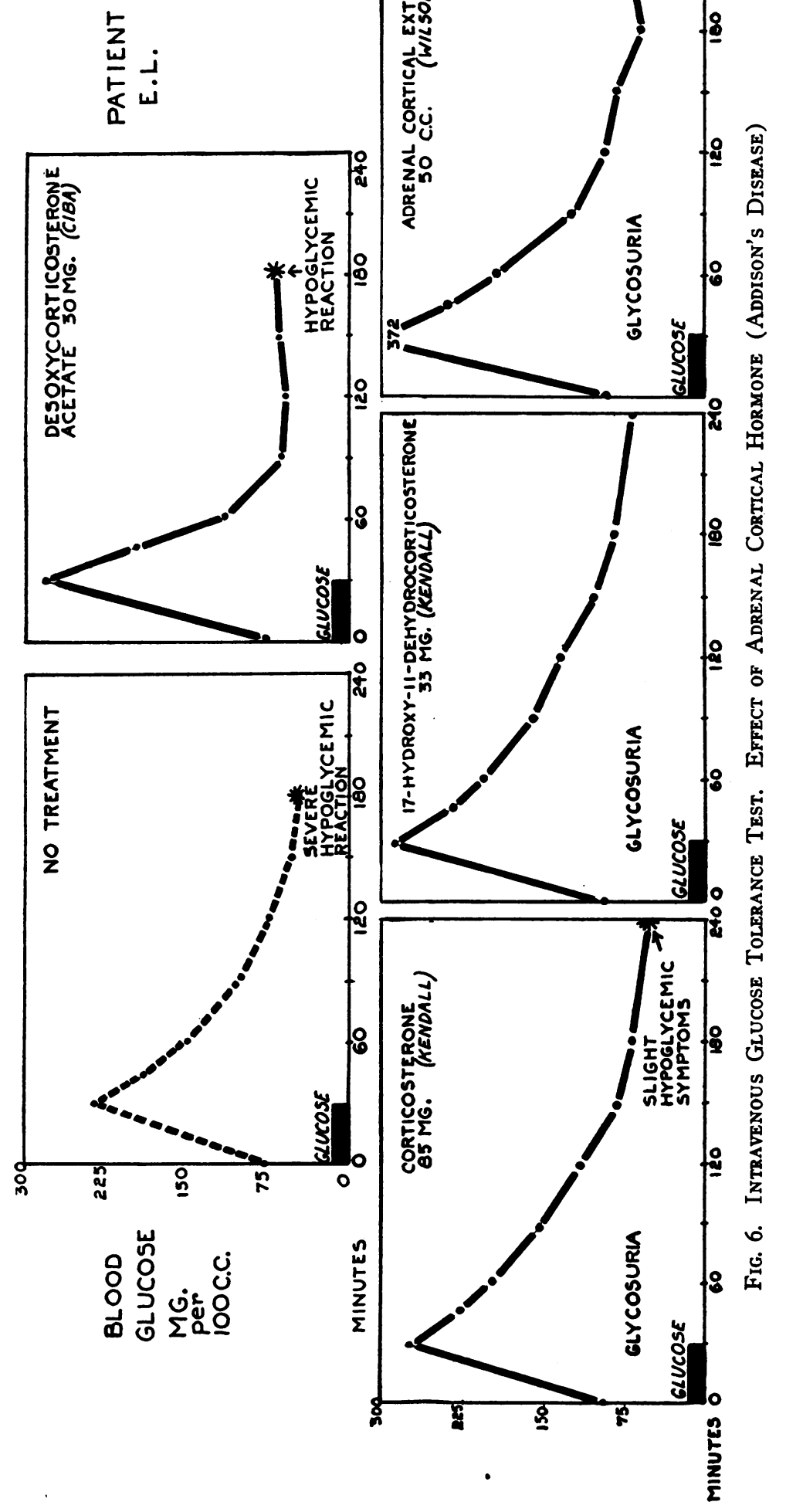


cose by vein and orange juice by mouth were required. However, this marked disturbance did not occur in all patients with Addison's disease (Figure 5). In the patients with the "carbohydrate defect," three changes were of particular interest: (1) the ease with which hypoglycemia was precipitated; (2) the severity of the symptoms and the great difficulty which was experienced in spontaneously recovering from the induced hypoglycemia; and (3) a definite lowering hydroxy-11-dehydrocorticosterone (33 mgm.) or large doses of adrenal cortical extract ( 50 to 70 cc.) completely prevented the appearance of symptoms of hypoglycemia and, in addition, increased the blood glucose level throughout the test. Normally, glycosuria was never observed during the glucose tolerance test of patients with Addison's disease. Following treatment with large quantities of adrenal cortical extract, 17-hydroxy-11dehydrocorticosterone and corticosterone, glyco-

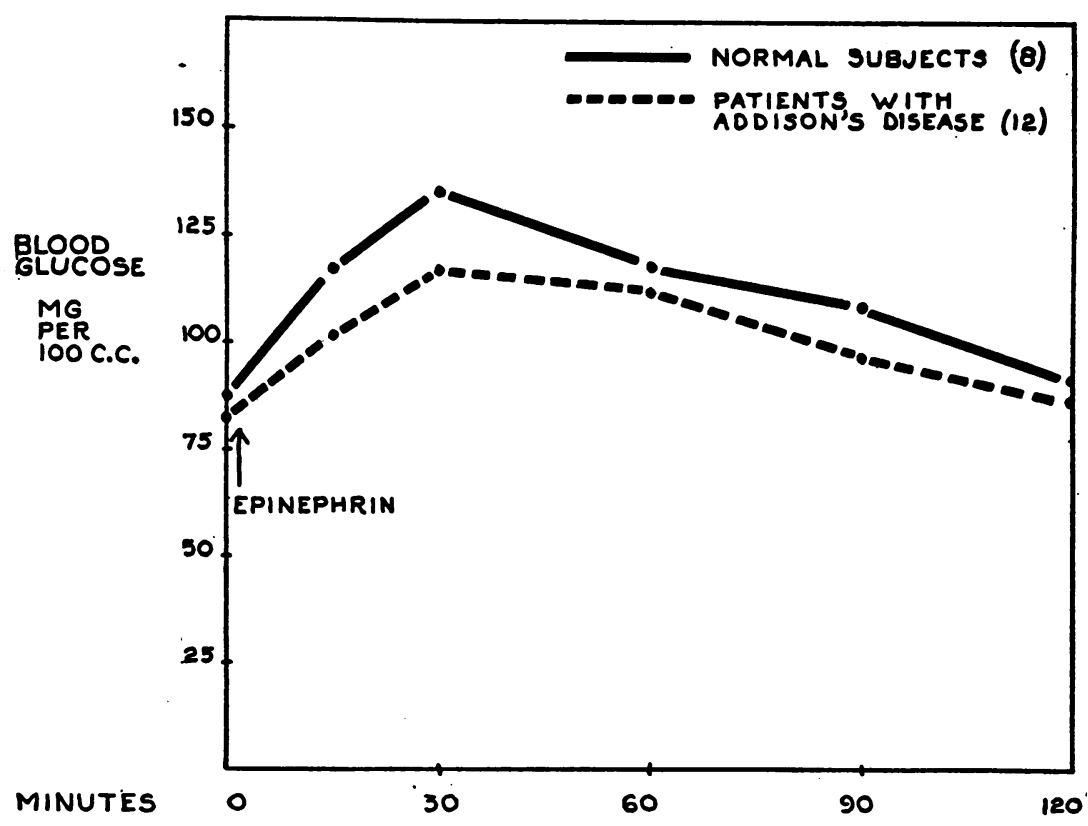

Fig. 7. Response to EPINEPhrin

of the threshold at which symptoms became manifest, since untreated patients with Addison's disease frequently developed marked symptoms of hypoglycemia at a blood glucose level which did not produce symptoms in normal subjects.

Treatment with certain adrenal cortical hormone preparations (large quantities of adrenal cortical extract, corticosterone and 17-hydroxy-11-dehydrocorticosterone) was followed by an increase in the fasting blood glucose level, an increase in the height of the glucose curve and an absence of signs and symptoms of hypoglycemia (Figure 6). Desoxycorticosterone acetate $(30 \mathrm{mgm}$.) treatment ameliorated the symptoms of hypoglycemia but did not affect the blood sugar level; corticosterone ( $85 \mathrm{mgm}$.) both ameliorated the symptoms and delayed their onset; treatment with 17- suria occurred during the standard intravenous glucose tolerance test.

\section{Epinephrin test}

The decreased glycemic response of patients with Addison's disease to a standard dose of epinephrin is illustrated in Figure 7. It is also of some interest to note that the injection of epinephrin during the hypoglycemic reaction precipitated by the standard intravenous glucose tolerance test was followed by a prompt but temporary rise in blood sugar level associated with a temporary remission in the hypoglycemic signs and symptoms (Figure 8). The immediate and transient effect of epinephrin in raising the blood glucose level is in marked contrast to the slower 


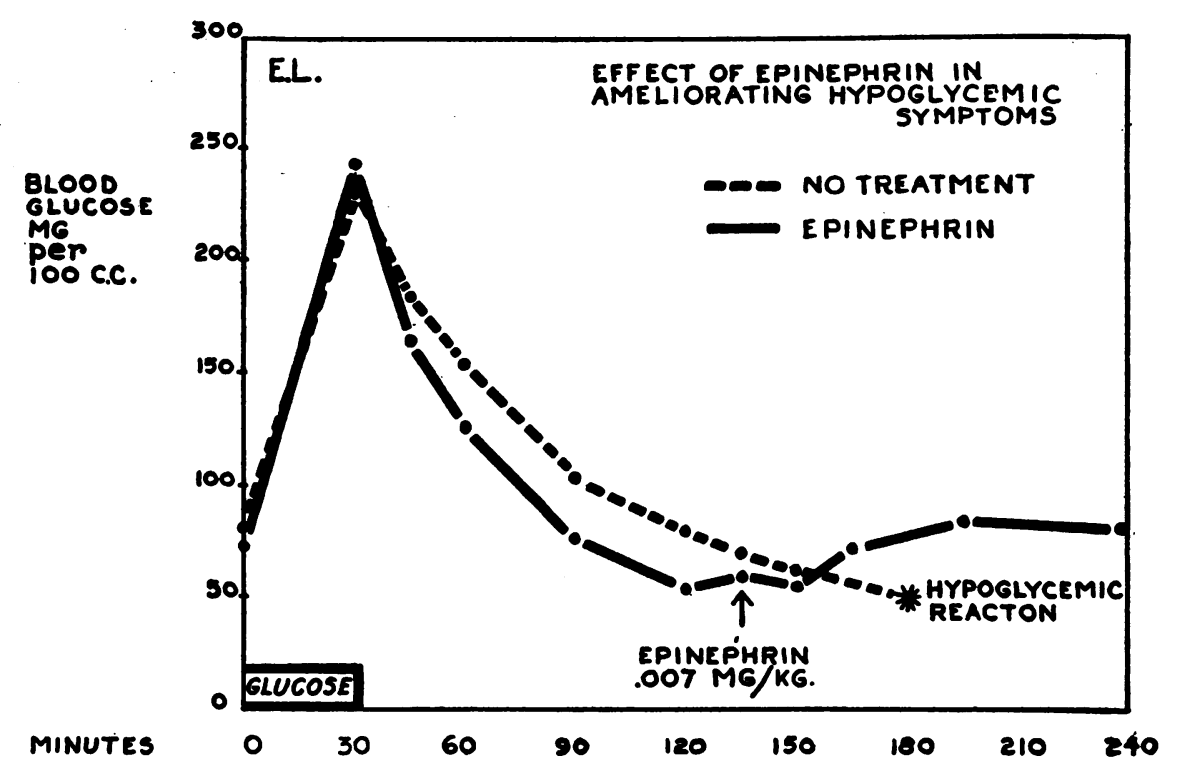

Fig. 8. Intravenous Glucose Tolerance Test (Addison's Disease)

and more prolonged action of adrenal cortical hormone ( 4 to 24 hours).

In one patient the response to epinephrin following an overnight fast was observed in the untreated state and again after several days of treatment with adequate doses of adrenal cortical hormone (20 cc. daily, injected subcutaneously). Associated with treatment there was a small but definite increase in the height of the blood glucose curve, an increment of $27,15,11,3 \mathrm{mgm}$., respectively, at 15, 30, 60 and 90 minutes following the subcutaneous injection of epinephrin (see methods).

\section{Response to insulin}

Because of the profound reaction of patients with Addison's disease to relatively small doses of insulin, we did not study the action of this hormone in human subjects. In bilaterally adrenalectomized dogs (to be reported elsewhere), it was demonstrated that treatment ( 6 to 18 hours beforehand) with 50 to $80 \mathrm{cc}$. of adrenal cortical extract completely prevented the severe and often fatal hypoglycemic reaction which followed the intravenous injection of 0.25 units of insulin per kgm. Large quantities of desoxycorticosterone acetate (50 mgm. or more) were ineffective in preventing convulsions. Treatment with 17 -hydroxy-11-dehydrocorticosterone, however, in a dose of $10 \mathrm{mgm}$., permitted the animal to survive the test without supplementary glucose therapy. The limited quantity of crystalline hormone available did not permit an exact determination of equivalent quantities of adrenal cortical extract and crystalline 17-hydroxy-11-dehydrocorticosterone.

\section{Standard metabolism}

The standard metabolism of patients with Addison's disease has been considered to be definitely lower than that of normal subjects. The values. which were obtained in 15 untreated patients are given in Figure 9. In our experience a basal

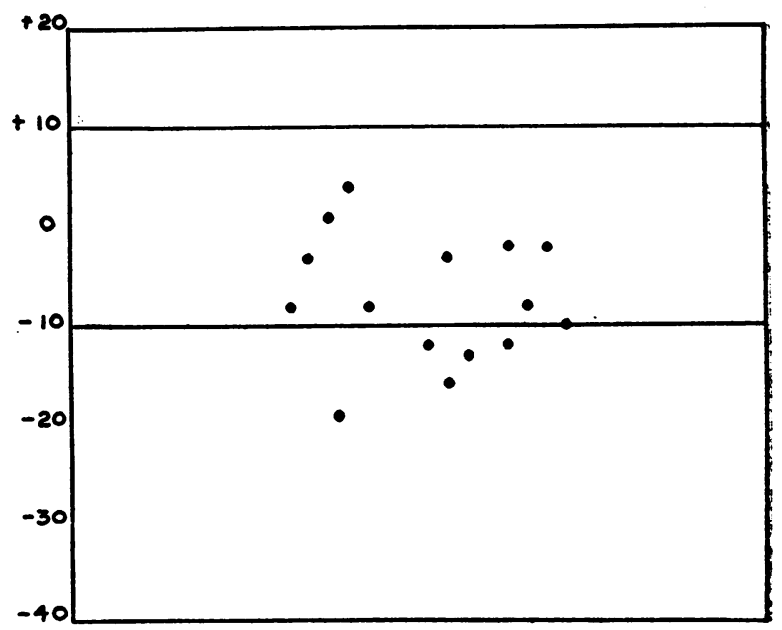

Fig. 9. Basal Metabolic Rate in 15 Patients with Addison's Disease (Untreated) 


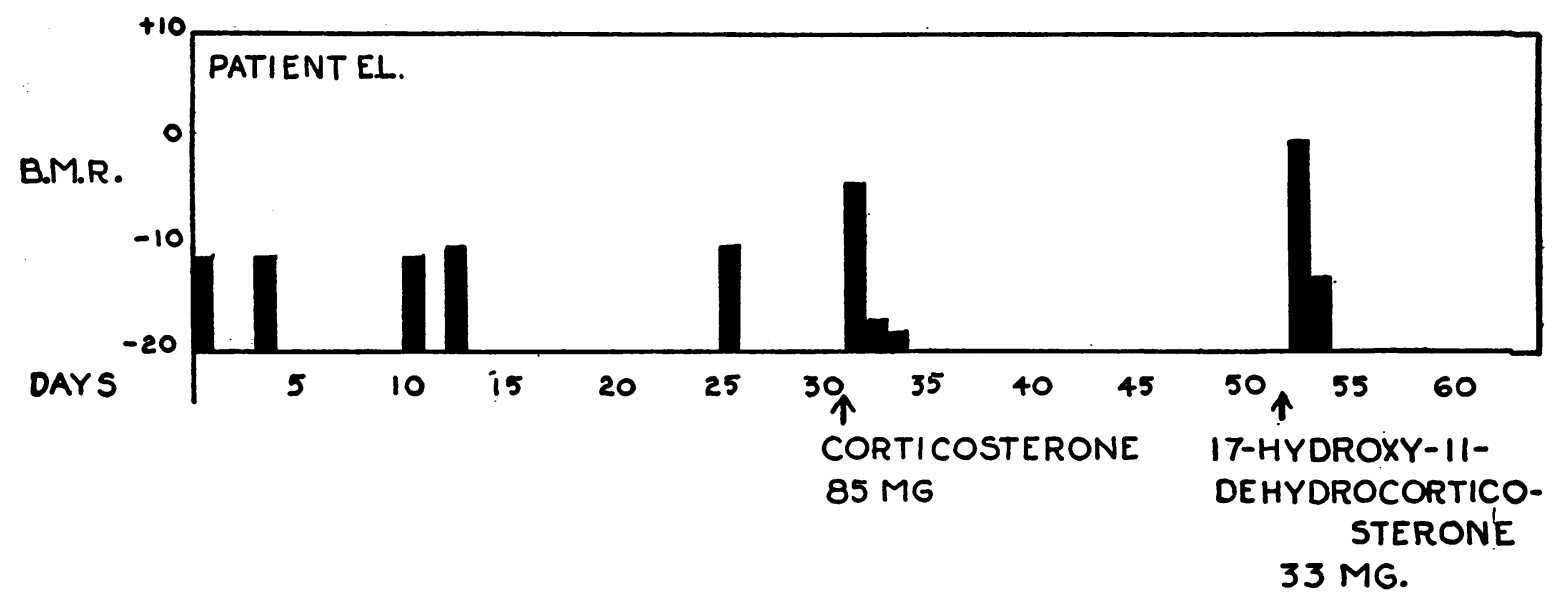

Fig. 10. The Effect of Adrenal Cortical Hormone Treatment on Basal Metabolic Rate (AdDison's Disease)

metabolic rate lower than -20 per cent is unusual in patients with Addison's disease uncomplicated by thyroid or pituitary deficiency.

In a group of 7 patients, no significant change in the average basal metabolic rate was noted following continued treatment with desoxycorticosterone acetate. The average value before treatment was -10 per cent (18 determinations) and during treatment -12 per cent (10 determinations). However, treatment with corticosterone or 17-hydroxy-11-dehydrocorticosterone was followed by a significant rise in the standard metabolism of Patient E. L. (Figure 10).

\section{Standard respiratory quotient}

A comparison between the standard respiratory quotient of 6 normal subjects and 8 patients with Addison's disease revealed no significant difference between the average of the two groups (Table III). However, if the values for 3 patients (S. P., A. H., and A. S.) who were observed to have no demonstrable abnormality in carbohydrate metabolism (see intravenous glucose tolerance tests, Table II) are excluded, the average value for the group of patients with the "carbohydrate-defect" is approximately 0.90 . This value is significantly higher than the value for the group of control subjects.

Prolonged treatment with desoxycorticosterone acetate (maintenance dose) had no effect on the standard respiratory quotient of 3 patients (E. L., A. H., M. B., Table IV). Treatment with large
TABLE III

Standard respiratory quotient

(Constant dietary regimen)

\begin{tabular}{|c|c|c|c|c|}
\hline \multicolumn{5}{|c|}{ ADDISON'S DISEASE } \\
\hline Patient & Sex & Age & Weight & Respiratory quotient \\
\hline $\begin{array}{l}\text { E.L.... } \\
\text { J.P.... } \\
\text { M.B... } \\
\text { Y.E. . } \\
\text { O.O. . } \\
\text { A.S.... } \\
\text { S.P.... } \\
\text { A.H. . }\end{array}$ & $\begin{array}{l}\mathbf{F} \\
\mathbf{M} \\
\mathbf{F} \\
\mathbf{F} \\
\mathbf{M} \\
\mathbf{M} \\
\mathbf{M} \\
\mathbf{F}\end{array}$ & $\begin{array}{l}51 \\
21 \\
31 \\
39 \\
43 \\
33 \\
27 \\
20\end{array}$ & $\begin{array}{l}k g m . \\
48 \\
45 \\
48 \\
54 \\
59 \\
57 \\
70 \\
57\end{array}$ & $\begin{array}{l}0.92,0.90,0.93,0.91,0.85,0.87 \text {, } \\
0.90,0.92 \\
0.90,0.90 \\
0.88,0.86,0.86,0.87 \\
0.90 \\
0.92 \\
0.87,0.92,0.87,0.86 \\
0.86,0.83,0.79 \\
0.85,0.86,0.83,0.84\end{array}$ \\
\hline \multicolumn{4}{|c|}{ Weighted average } & 0.88 \\
\hline \multicolumn{5}{|c|}{ NORMAR SUBJECTS } \\
\hline $\begin{array}{l}\text { F.A.... } \\
\text { S.A.... } \\
\text { R.L. . } \\
\text { C.D. . } \\
\text { V.H... } \\
\text { J.B.... }\end{array}$ & $\begin{array}{l}\mathbf{M} \\
\mathbf{M} \\
\mathbf{M} \\
\mathbf{M} \\
\mathbf{F} \\
\mathbf{F}\end{array}$ & $\begin{array}{l}21 \\
23 \\
28 \\
26 \\
30 \\
37\end{array}$ & $\begin{array}{l}60 \\
81 \\
75 \\
84 \\
47 \\
58\end{array}$ & $\begin{array}{l}0.89 \\
0.84 \\
0.82,0.82,0.80 \\
0.85,0.86 \\
0.87 \\
0.88,0.86\end{array}$ \\
\hline \multicolumn{4}{|c|}{ ighted average } & 0.86 \\
\hline
\end{tabular}

quantities of adrenal cortical extract (20 to 70 cc.) corticosterone ( $85 \mathrm{mgm}$.) or 17-hydroxy-11dehydrocorticosterone (33 $\mathrm{mgm}$.) was followed by a striking reduction in the standard respiratory quotient when treatment was instituted 12 to 18 hours preceding the test (Patient E. L., Table IV). The reduction in standard respiratory quotient was accompanied by a rise in fasting blood 


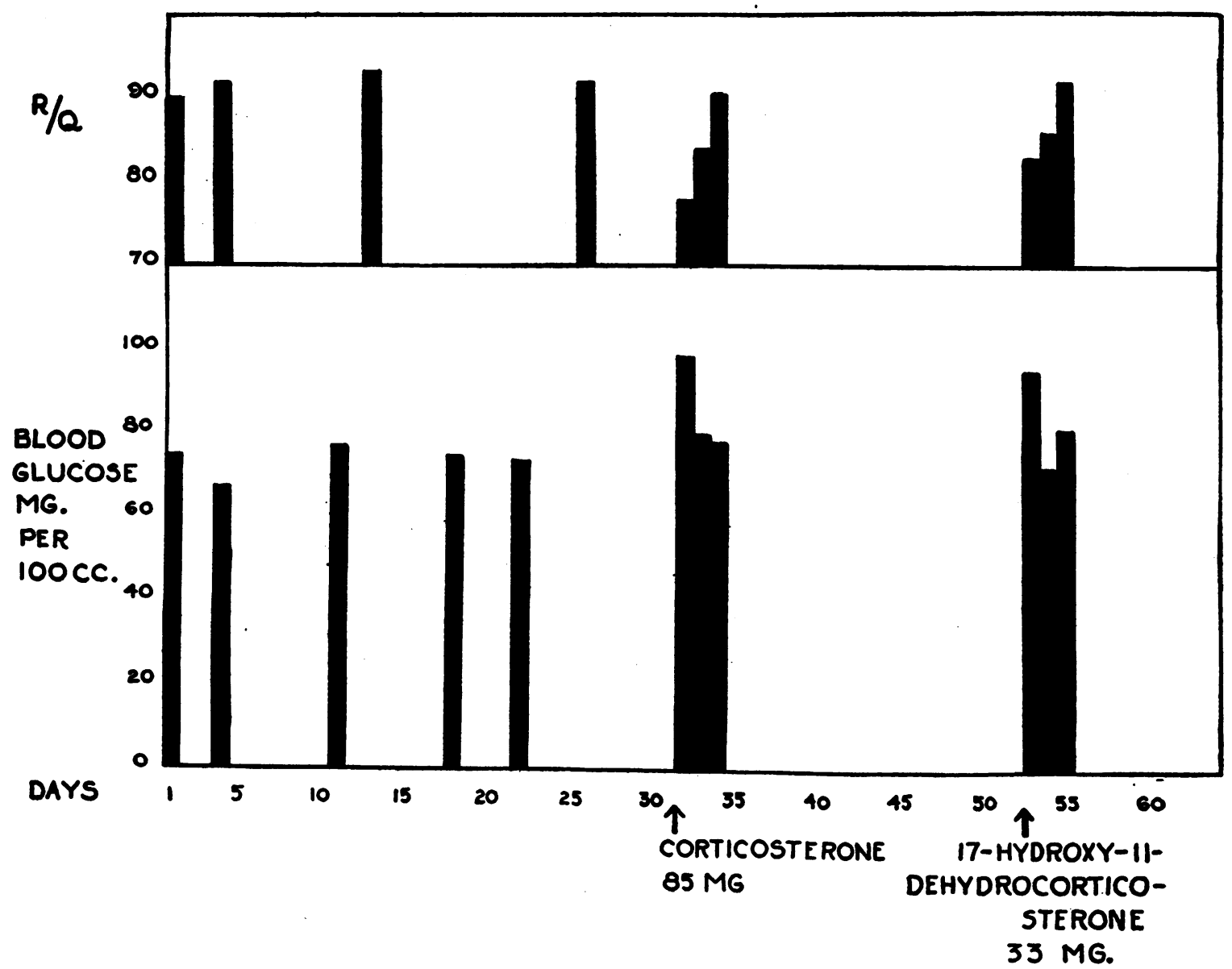

Fig. 11. The Efmect of Adrenal Cortical hormone Treatment on Standard R.Q. and Blood Gzucose (AdDison's DiseasE)

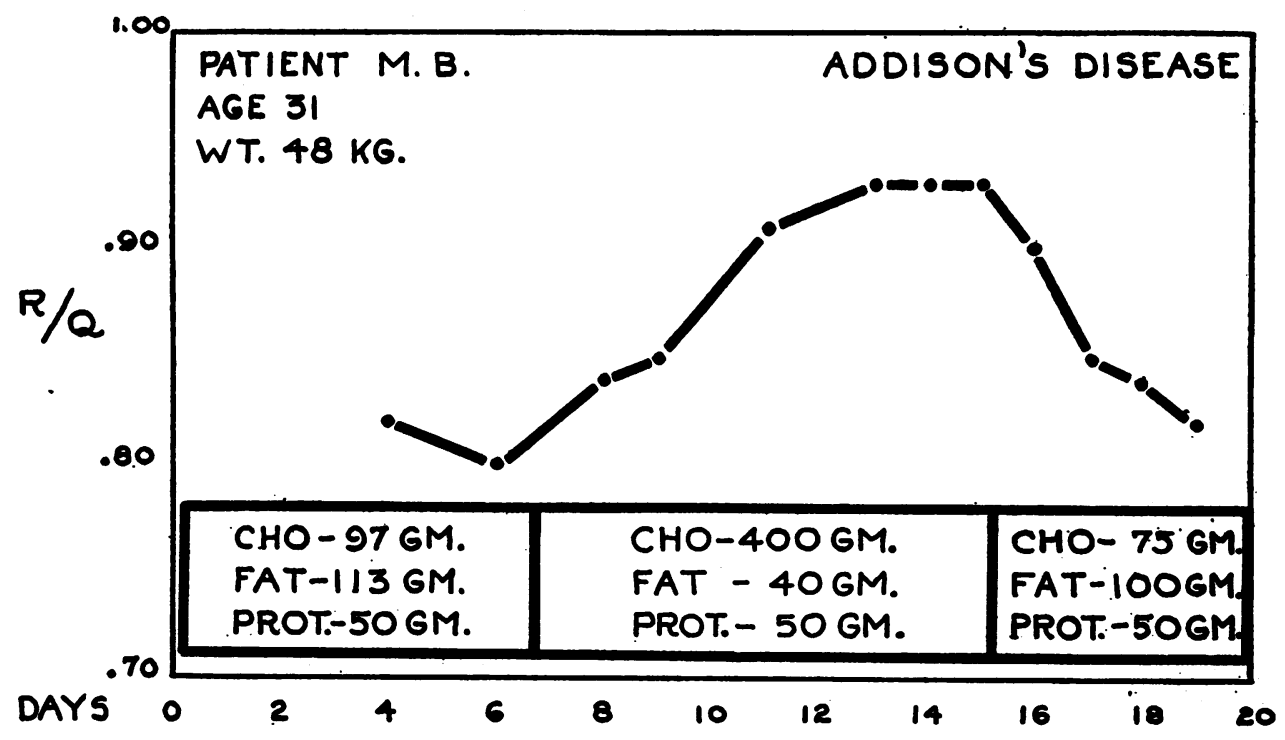

Fig. 12. The Effect of Diet on Standard R.Q. 
TABLE IV

Effect of adrenal cortical hormone on standard respiratory quotient

\begin{tabular}{|c|c|c|c|c|c|}
\hline Patient & $\begin{array}{c}\text { No } \\
\text { Treat- } \\
\text { ment }\end{array}$ & $\begin{array}{c}\text { Desoxy- } \\
\text { corticos- } \\
\text { terone } \\
\text { acetate } \\
\text { 2-10 mgm. } \\
\text { daily }\end{array}$ & $\begin{array}{l}\text { Adrenal } \\
\text { cortical } \\
\text { extract } \\
50-70 \mathrm{cc} .\end{array}$ & $\begin{array}{l}\text { Corticos- } \\
\text { terone } \\
85 \text { mgm. }\end{array}$ & $\begin{array}{l}\text { 17-hydroxy- } \\
\text { 11-dehydro- } \\
\text { corticos- } \\
\text { terone } \\
33 \text { mgm. }\end{array}$ \\
\hline $\begin{array}{l}\text { E.L..... } \\
\text { J.P..... } \\
\text { M.B... } \\
\text { A.H.... }\end{array}$ & $\begin{array}{l}0.90 \\
0.88 \\
0.84\end{array}$ & $\begin{array}{l}0.90 \\
0.90 \\
0.87 \\
0.84\end{array}$ & $\begin{array}{l}0.85 \\
0.84\end{array}$ & 0.78 & 0.83 \\
\hline
\end{tabular}

glucose (Figure 11). It is particularly significant that 48 hours after treatment with these substances had been discontined the standard respiratory quotient and the fasting blood glucose value had returned to the previous untreated level (Figure 11). No ketonuria was observed during the short period of treatment with adrenal cortical extract, corticosterone or 17-hydroxy-11-dehydrocorticosterone. The possibility of ketonemia was not excluded.

In another type of experiment the effect of diet was observed on the standard respiratory quotient of normal subjects and patients with Addison's disease. An increase in the proportion of carbohydrate in the diet (protein and total calories being kept constant) resulted in a striking rise in the standard respiratory quotient of untreated patients with Addison's disease (Patient M. B., Figure 12) as well as in normal control subjects.

\section{Respiratory quotient following the intravenous administration of glucose}

Because of the striking abnormality which was observed in the intravenous glucose curve of patients with Addison's disease, it seemed desirable to follow closely the changes in respiratory metabolism which occurred during this test. The respiratory quotient, total urinary nitrogen excretion and blood glucose values of 4 normal subjects and 5 patients with Addison's disease were followed during the standard intravenous glucose tolerance test (Table V). The respiratory quotient rose to 0.90 or above in only one of the 4 normal subjects, whereas it exceeded 0.90 in all 5 of the patients with Addison's disease. Particularly noteworthy was the sudden and striking fall in respiratory quotient in Patients E. L., J. P., and M. B., as marked hypoglycemic symptoms be-
TABLE $V$

Changes in respiratory quotient, urinary nitrogen and blood glucose following the intravenous administration of glucose

NORMAL SUBJECTS

\begin{tabular}{|c|c|c|c|c|c|c|}
\hline & & $\begin{array}{c}\text { Ini- } \\
\text { tial } \\
\text { fast- } \\
\text { ing }\end{array}$ & hour & $\dot{2} 2$ & $\begin{array}{c}3 \\
\text { hours }\end{array}$ & $\begin{array}{c}4 \\
\text { hours }\end{array}$ \\
\hline S.A... & $\begin{array}{l}\text { Respiratory quotient } \\
\text { Urinary nitrogen } \\
\text { Blood glucose } \dagger\end{array}$ & \begin{tabular}{r|}
0.84 \\
0.55 \\
87
\end{tabular} & $\begin{array}{r}0.85 \\
0.67 \\
110\end{array}$ & $\begin{array}{r}0.84 \\
0.90 \\
76\end{array}$ & $\begin{array}{r}0.83 \\
0.90 \\
81\end{array}$ & $\begin{array}{r}0.80 \\
0.56 \\
78\end{array}$ \\
\hline F.A... & $\begin{array}{l}\text { Respiratory quotient } \\
\text { Urinary nitrogen } \\
\text { Blood glucose }\end{array}$ & $\begin{array}{r}0.90 \\
0.31 \\
81\end{array}$ & $\begin{array}{r}0.94 \\
0.43 \\
164\end{array}$ & $\begin{array}{r}0.94 \\
0.45 \\
67\end{array}$ & $\begin{array}{r}0.82 \\
0.45 \\
82\end{array}$ & $\begin{array}{r}0.83 \\
0.32 \\
106\end{array}$ \\
\hline R.L. . & $\begin{array}{l}\text { Respiratory quotient } \\
\text { Urinary nitrogen } \\
\text { Blood glucose }\end{array}$ & $\begin{array}{r}0.82 \\
0.34 \\
95\end{array}$ & $\begin{array}{l}0.82 \\
0.56 \\
164\end{array}$ & $\begin{array}{r}0.84 \\
0.50 \\
75\end{array}$ & $\begin{array}{r}0.82 \\
0.47 \\
64\end{array}$ & 68 \\
\hline C.D. & $\begin{array}{l}\text { Respiratory quotient } \\
\text { Urinary nitrogen } \\
\text { Blood glucose }\end{array}$ & $\begin{array}{r}0.85 \\
0.42 \\
89\end{array}$ & $\begin{array}{r}0.88 \\
0.66 \\
70\end{array} \mid$ & $\begin{array}{r}0.77 \\
0.66 \\
78\end{array}$ & $\begin{array}{r}0.79 \\
0.83 \\
84\end{array}$ & $\begin{array}{r}0.78 \\
0.80 \\
87\end{array}$ \\
\hline
\end{tabular}

PATIENTS WITH ADDISON'S DISEASE

\begin{tabular}{|c|c|c|c|c|c|c|}
\hline E.L... & $\begin{array}{l}\text { Respiratory quotient } \\
\text { Urinary nitrogen } \\
\text { Blood glucose }\end{array}$ & $\begin{array}{r}0.90 \\
0.43 \\
76\end{array}$ & $\begin{array}{r}0.92 \\
0.35 \\
153\end{array}$ & $\begin{array}{l}0.94 \\
0.24 \\
77\end{array}$ & $\begin{array}{l}0.77^{*} \\
0.20^{*} \\
50^{*}\end{array}$ & \\
\hline J.P... & $\begin{array}{l}\text { Respiratory quotient } \\
\text { Urinary nitrogen } \\
\text { Blood glucose }\end{array}$ & $\begin{array}{r}0.90 \\
0.27 \\
79\end{array}$ & $\begin{array}{r}1.03 \\
0.49 \\
192\end{array}$ & $\begin{array}{r}0.98 \\
0.37 \\
99\end{array}$ & $\begin{array}{l}0.78^{*} \\
0.24^{*} \\
62^{*}\end{array}$ & \\
\hline M.B.. & $\begin{array}{l}\text { Respiratory quotient } \\
\text { Urinary nitrogen } \\
\text { Blood glucose }\end{array}$ & \begin{tabular}{r|}
0.88 \\
0.24 \\
78
\end{tabular} & $\begin{array}{r}0.95 \\
105\end{array}$ & $\begin{array}{c}0.80 * \\
48 *\end{array}$ & & \\
\hline S.P... & $\begin{array}{l}\text { Respiratory quotient } \\
\text { Urinary nitrogen } \\
\text { Blood glucose }\end{array}$ & $\begin{array}{r}0.86 \\
0.41 \\
95\end{array}$ & $\begin{array}{r}0.89 \\
0.53 \\
182\end{array}$ & $\begin{array}{r}0.96 \\
0.46 \\
94\end{array}$ & $\begin{array}{r}0.93 \\
0.37 \\
91\end{array}$ & $\begin{array}{r}0.92 \\
0.32 \\
88\end{array}$ \\
\hline A.H. . & $\begin{array}{l}\text { Respiratory quotient } \\
\text { Urinary nitrogen } \\
\text { Blood glucose }\end{array}$ & $\begin{array}{r}0.86 \\
0.33 \\
88\end{array}$ & $\begin{array}{r}0.91 \\
0.41 \\
187\end{array}$ & $\mid \begin{array}{l}0.87 \\
0.34 \\
94\end{array}$ & $\begin{array}{r}0.76 \\
0.34 \\
70\end{array}$ & $\begin{array}{r}0.79 \\
0.39 \\
70\end{array}$ \\
\hline
\end{tabular}

* Total urinary nitrogen, expressed as grams per hour.

† Blood glucose expressed as mgm. per $100 \mathrm{cc}$.

came manifest. It is obvious that determinations of respiratory quotient made at this time are subject to error, but the fact that all 3 of the patients had such sudden and striking changes in the same direction may be of some significance.

The effect of treatment with large quantities of adrenal cortical extract (Wilson's 50 to 70 cc.), crystalline desoxycorticosterone acetate (30 $\mathrm{mgm}$.), corticosterone ( $85 \mathrm{mgm}$.) and 17-hydroxy-11-dehydrocorticosterone (33 $\mathrm{mgm}$.) on the respiratory quotient of Patient E. L., is recorded in Figure 13. Continued treatment with maintenance doses of desoxycorticosterone acetate or treatment immediately beforehand with a mod- 


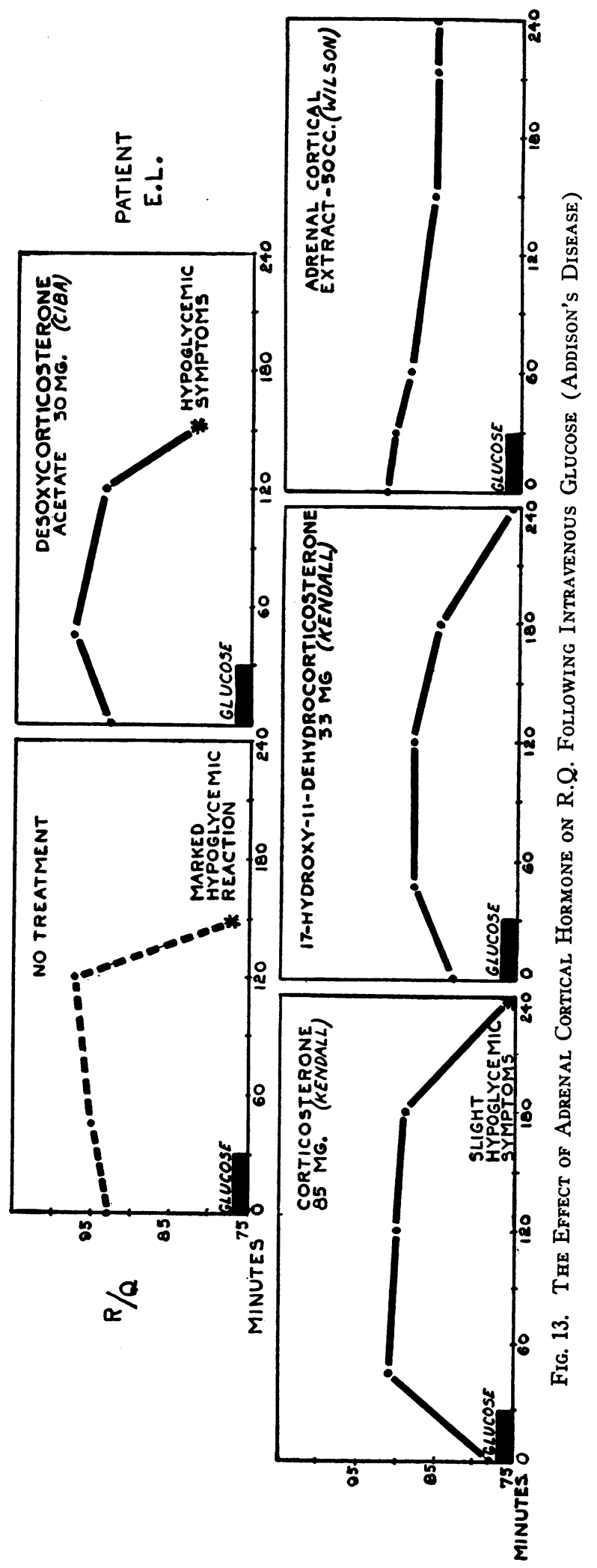




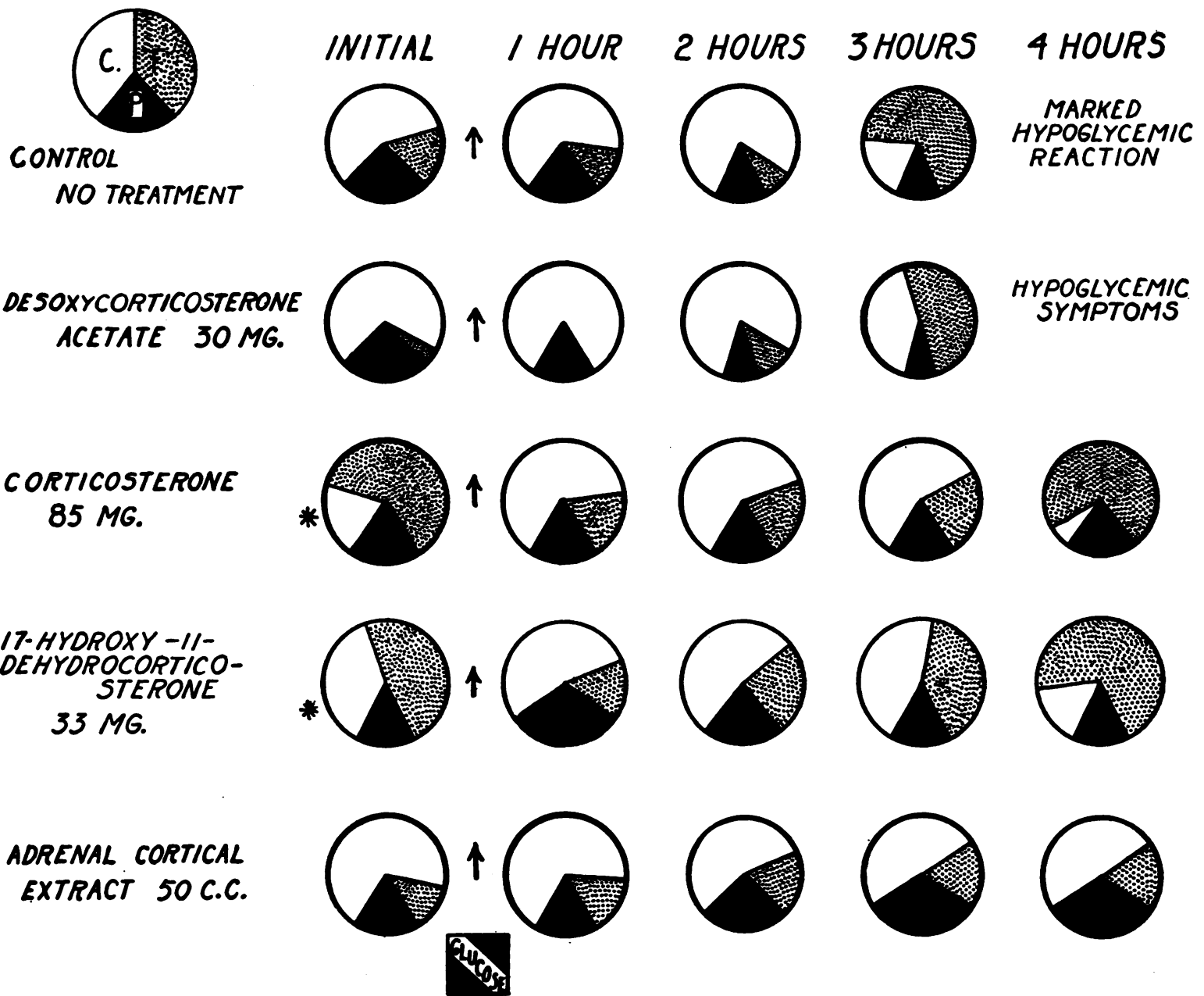

Fig. 14: Addison's Disease. E. L. Caloric Changes Following Intravenous Glucose

erately large dose of this compound (30 mgm.) was not associated with any change in the respiratory quotient. Treatment with $50 \mathrm{cc}$. of adrenal cortical extract, injected 4 to 6 hours previous to the test, did not affect the initial standard respiratory quotient but was associated with a marked change in the subsequent respiratory quotient values (Figure 13, Patient E. L.). In another experiment (Figure 11) it was observed that treatment with 50 to $70 \mathrm{cc}$. of adrenal cortical extract during a 12- to 24-hour period preceding the test significantly affected the initial respiratory quotient. Treatment with corticosterone and with 17-hydroxy-11-dehydrocorticosterone (dissolved in oil and injected intramuscularly during a 12-hour period prior to the standard intravenous glucose tolerance test) was followed by a marked reduction in initial standard respiratory quotient, as well as in the values following the intravenous glucose tolerance test (Figure 13).

Differential derivation of calories (Lusk's table) indicated that in the untreated state (Patient E. L., Figure 14) a high proportion of calories was derived from carbohydrate oxidation following the intravenous administration of glucose, particularly during the second hour of the test. During the third hour of the test, in the untreated patient, there was a sudden reduction in the proportion of calories derived from carbohydrate (low $R / Q$ ) immediately preceding the onset of marked symptoms of hypoglycemia. Treatment with desoxycorticosterone acetate had no effect on these changes. Treatment with adrenal cortical extract, 17-hydroxy-11-dehydrocorticosterone and corticosterone (in order of potency) was followed by a significant reduction in the proportion of 


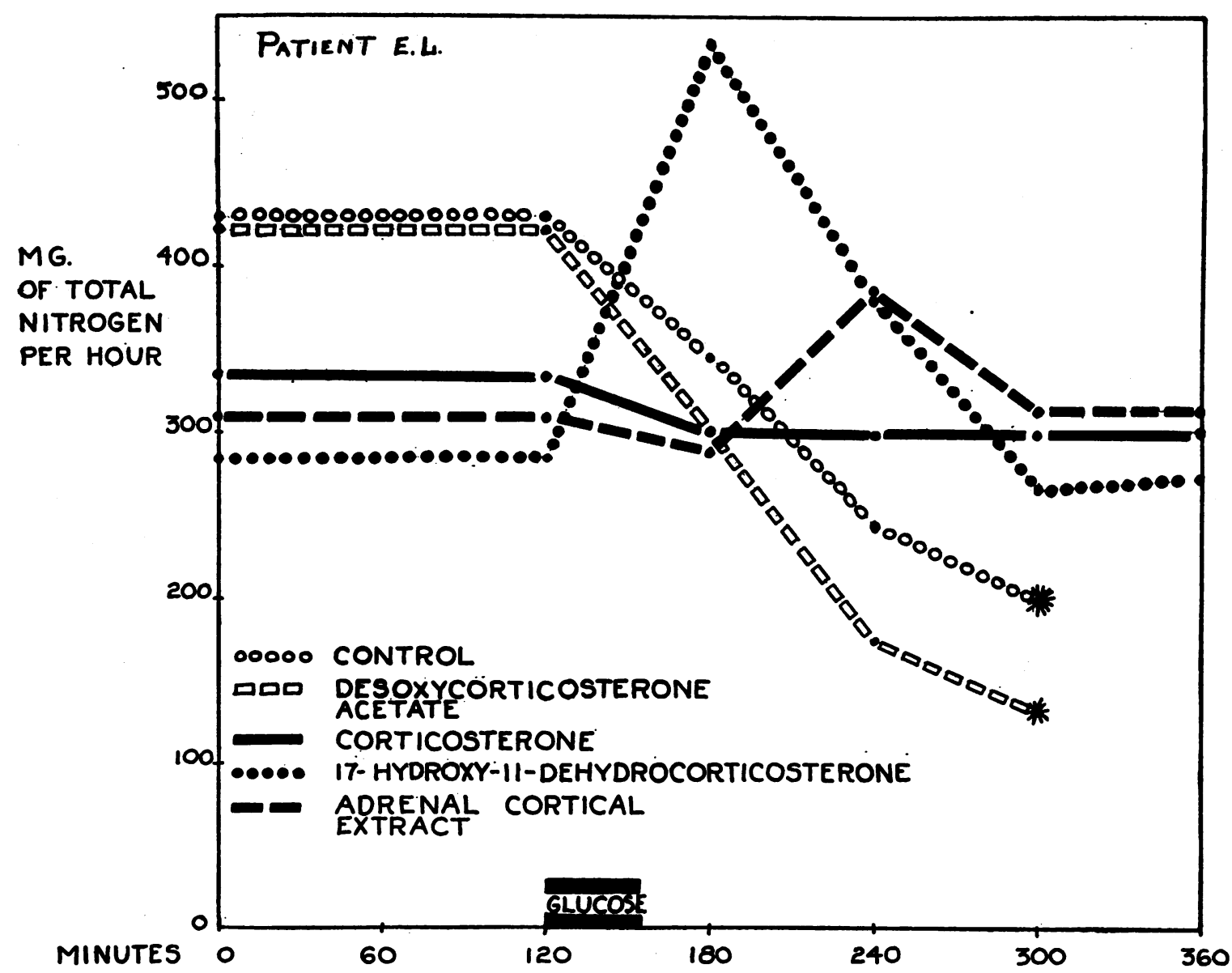

Fig. 15. Effect of Adrenal Cortical Hormone Therapy on Urinary Excretion of Nitrogen During Standard Intravenous Glucose Tolerance Test

calories derived from carbohydrate during the initial periods of the test (first and second hours). During the third and fourth hours of the test, following treatment with these three substances, there was an increase in the proportion of calories derived from carbohydrate and protein. The increase in calories derived from protein was particularly striking following adrenal cortical extract therapy.

The excellent clinical condition of patient E. L. at the termination of the intravenous glucose tolerance test following treatment with adrenal cortical extract and 17-hydroxy-11-dehydrocorticosterone warrants mention (see Figure 6). Furthermore, it is significant that signs and symptoms of hypoglycemia did not become manifest during treatment with these substances although the blood glucose, on some occasions, was reduced to the level at which signs and symptoms had appeared in the untreated state.

\section{Urinary nitrogen excretion}

The rise in urinary nitrogen excretion which was observed during the standard intravenous

TABLE VI

Total urinary nitrogen excretion (grams per hour) during standard intravenous glucose tolerance test

\begin{tabular}{l|c|c|c|c|c}
\hline \hline & Fasting & $\begin{array}{c}1 \\
\text { hour }\end{array}$ & $\begin{array}{c}2 \\
\text { hours }\end{array}$ & $\begin{array}{c}3 \\
\text { hours }\end{array}$ & $\begin{array}{c}4 \\
\text { hours }\end{array}$ \\
\hline $\begin{array}{r}\text { 4 Control subjects... } \\
\text { 4 Patients with Addi- } \\
\text { son's disease....... }\end{array}$ & 0.40 & 0.58 & 0.63 & 0.66 & 0.56 \\
\hline
\end{tabular}

glucose tolerance test was greater and more sustained in control subjects than in patients with Addison's disease (Table VI). In Patient E. L. 
(Figure 15), treatment with 17-hydroxy-11-dehydrocorticosterone and with adrenal cortical extract was followed by a striking rise in the urinary excretion of nitrogen during the intravenous glucose tolerance test. Treatment with desoxycorticosterone acetate was without effect, and treatment with corticosterone was followed by a change, intermediate between that of desoxycorticosterone acetate and 17-hydroxy-11-dehydrocorticosterone (Figure 15). It is of interest to note that the greatest increases in urinary nitrogen excretion followed treatment with those adrenal cortical hormone preparations which had previously been shown to be the most potent in regulating carbohydrate metabolism. It is possible, however, that the changes in the renal excretion of nitrogen following hormone treatment may be due in part to changes in renal " function."

\section{Prolonged fast}

Prolonged fasting was associated with a decrease in blood glucose, respiratory quotient and urinary nitrogen excretion (Patient M. B., Figure 16). Treatment with adrenal cortical extract was followed by a rise in blood glucose, a further decrease in respiratory quotient, and an increase in urinary nitrogen excretion.

It would appear that the efficacy of adrenal cortical hormone therapy in raising the blood glucose level during fasting was the result of increased glycogenesis without an equivalent increase in glucose utilization.

\section{Necessity for adequate carbohydrate in diet}

Studies (M. B., Figure 12) indicate that patients with Addison's disease can utilize the readily available carbohydrate contained in their diet. It has been suggested $(9,12)$ that patients with Addison's disease should be provided with a diet high in readily available carbohydrate, if hypoglycemia is to be avoided. A diet high in carbohydrate would appear to be essential for the successful treatment of Addison's disease, at least until treatment with hormone possessing carbohydrate-regulating property is available at a cost which most patients can afford.

The striking inability of these patients to derive sufficient carbohydrate from endogenous and exogenous non-carbohydrate sources was vividly

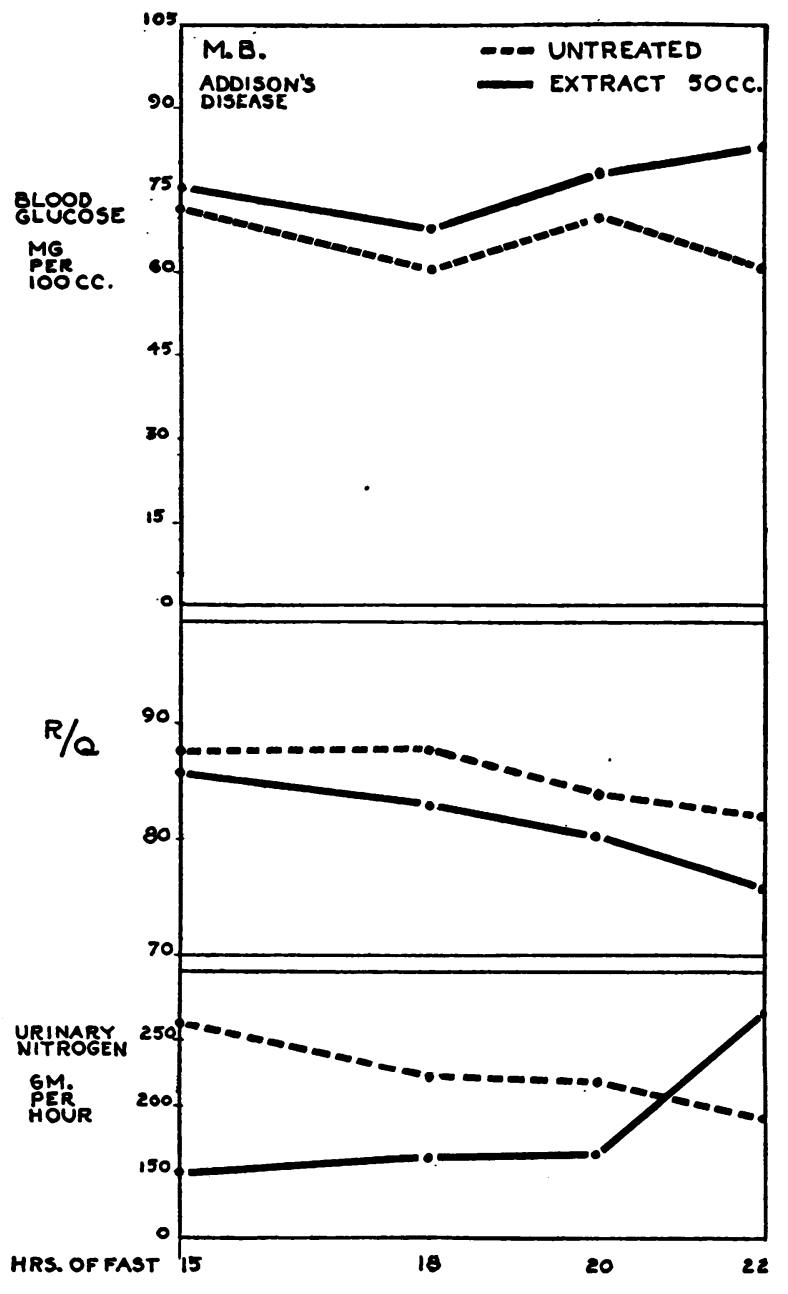

Fig. 16. Prolonged Fast

demonstrated by the course of events which occurred when Patient J. P., under carefully controlled conditions, was fed a diet low in carbohydrate. The composition of the diet was as follows :

\begin{tabular}{l|c|c|c}
\hline \hline & Carbohydrate & Fat & Protein \\
\hline First day......... & 50 & 120 & 45 \\
Second day...... & 17 & 130 & 30 \\
Third day...... & 10 & 130 & 35 \\
\hline
\end{tabular}

Throughout this study the patient received treatment with desoxycorticosterone acetate. On the evening of the third day, one hour after the ingestion of tea and cream, a severe hypoglycemic reaction occurred. This was characterized by deep respiration, profuse perspiration, hunger, 
weakness and nervousness progressing rapidly to marked mental confusion. The following data obtained at this time indicated that the reaction was specifically related to a disturbance in carbohydrate metabolism and not to a loss of sodium, chloride and water with subsequent dehydration:

1. No appreciable loss in body weight during the 3 days of the experiment.

2. Rapid recovery following intravenous glucose therapy without additional sodium chloride or adrenal cortical hormone therapy.

3. Hypoglycemia ( $55 \mathrm{mgm}$.) was associated with a normal concentration of sodium and chloride in the blood with evidence of only slight hemoconcentration: serum sodium 140 m.eq., chloride 101.4 m.eq., and potassium 6.1 m.eq., per liter; carbon dioxide combining power 49 volumes per cent; non-protein nitrogen 27 mgm. per 100 cc. The urine contained acetone bodies $4+$.

The slightly higher-than-normal serum potassium value may be of some significance in association with the low blood glucose level (13).

Thus within a period of 72 hours, during which he received a diet of adequate caloric content, and during a period in which blood pressure, plasma volume and electrolyte balance were maintained by means of desoxycorticosterone acetate treatment, this patient developed a severe hypoglycemic reaction. This study demonstrates the decreased glycogenesis which is associated with Addison's disease, as well as the inability of desoxycorticosterone acetate treatment to increase the formation of glucose from non-carbohydrate sources.

\section{Hypoglycemia precipitated by intercurrent infections}

Acute respiratory infections and gastro-enteritis constitute the most frequent complications which precipitate hypoglycemia in patients with Addison's disease. If not recognized and treated this complication may result in a fatal outcome.

In the absence of complications, treatment with desoxycorticosterone acetate maintained a majority of patients with Addison's disease (12) in good clinical condition without supplementary treatment with specific carbohydrate-regulating factor. The frequent ingestion of food provided an ade- quate supply of readily available carbohydrate. However, when this source of supply was restricted (fasting, nausea, vomiting), or when the demand for carbohydrate was increased (fever, infection), the blood glucose level rapidly declined and severe hypoglycemic symptoms appeared despite adequate desoxycorticosterone acetate therapy. The reasons for the rapid onset of hypoglycemia in these patients appeared to be two-fold: (a) oxidation of carbohydrate which rapidly depleted available stores; and $(b)$ inability to form adequate quantities of carbohydrate from nonglucose sources.

At present the only form of specific hormone therapy possessing carbohydrate-regulating factor which is available commercially is adrenal cortical extract. This must be used in large doses, 20 to $50 \mathrm{cc}$. daily, in the presence of severe infection. In addition, it is desirable to provide carbohydrate by parenteral administration of glucose solutions, if patients are unable to take adequate quantities of fruit juice, lactose, gingerale, etc., by mouth.

\section{Lactic acid}

Because of the position of lactic acid as a transition substance between protein and glycogen, and its importance in glucose oxidation, it seemed desirable to study its glycogenic action in patients with Addison's disease and in adrenalectomized animals.

In Patient O. O. treatment with lactic acid (18 grams of racemic lactic acid administered intravenously as the sodium salt dissolved in $1000 \mathrm{cc}$. of water) failed to alleviate the symptoms of hypoglycemia which were initiated by the standard intravenous glucose tolerance test. Glucose administered intravenously 1 hour after the lactate solution had been started promptly corrected the hypoglycemia. These observations on patients were confirmed by experiments on adrenalectomized dogs (14) in which $d$-lactic acid administered intravenously failed to prevent the convulsions induced by insulin, whereas treatment with glucose completely prevented signs of hypoglycemia. Direct evidence of the diminished ability of untreated adrenalectomized animals to convert lactic acid to glucose has also been obtained in phlorhizinized adrenalectomized rats (14). 


\section{Physiological activity of steroid compounds obtained from the adrenal cortex}

To date numerous crystalline compounds have been isolated from adrenal cortical extracts. In the present study we have compared the effect of three of these compounds on carbohydrate metabolism in man. Desoxycorticosterone, which appears to be the most active adrenal cortical compound thus far isolated as measured by its ability to maintain the life of adrenalectomized animals, is very potent in electrolyte-regulating property (9). It appeared from this study that desoxycorticosterone treatment had little, if any, specific effect on carbohydrate metabolism in man. Corticosterone, a compound similar to desoxycorticosterone, but with an additional hydroxyl group, probably at $\mathrm{C}_{11}$, had less electrolyte-regulating property (15) than desoxycorticosterone, but it was much more potent in its carbohydrate-regulating effect. Seventeen-hydroxy-11-dehydrocorticosterone was more potent in carbohydrate-regulating property than either corticosterone or desoxycorticosterone, but appeared from animal experiments to be much less effective than either of these compounds in regulating electrolyte balance and in maintaining the life of adrenalectomized animals. Thus oxygenation of desoxycorticosterone in positions 11 and 17 greatly increased carbohydrate-regulating potency but at the same time greatly decreased electrolyte-regulating and life-maintaining properties.

Potent adrenal cortical extracts appeared to contain appreciable quantities of both electrolyte and carbohydrate-regulating factors. However, in man, relatively large quantities of extract must be given to demonstrate either effect. Doctor E. C. Kendall of the Mayo Clinic kindly supplied data regarding the approximate steroid content of Wilson's adrenal extract ( $50 \mathrm{cc}$. contains approximately $3 \mathrm{mgm}$. corticosterone, $3 \mathrm{mgm}$. dehydrocorticosterone, $3 \mathrm{mgm}$. 17-hydroxy-11-dehydrocorticosterone, $1 \mathrm{mgm}$. 17-hydroxycorticosterone, as well as unidentified substances). Our experiments suggest that the carbohydrate-regulating potency of this extract ( $50 \mathrm{cc}$. being as effective as $85 \mathrm{mgm}$. of corticosterone or $33 \mathrm{mgm}$. of 17-hydroxy-11-dehydrocorticosterone) is much greater than can be explained by its content of these two constituents.

\section{DISCUSSION}

A comparison between the oral and intravenous glucose tolerance curves indicates that the socalled " flat-curve" following orally administered glucose actually represents delayed or poor absorption of glucose. Similar changes have been observed in a patient with idiopathic steatorrhea (non-tropical sprue). It appears from these studies that a "flat-curve" following orally administered glucose is of little diagnostic significance.

The striking hypoglycemia which occurs in many patients with Addison's disease following the standard intravenous glucose tolerance test is of great clinical significance since it implies the existence of a marked disturbance in carbohydrate metabolism. The test is of considerable aid in diagnosis, although it is not specific. Its greatest usefulness lies in the ease with which it permits a disturbance in carbohydrate metabolism to be detected. The changes which were observed in patients following intravenous glucose administration were in many ways similar to the changes observed by Kendall et al (13) in adrenalectomized dogs. A comparison between intravenous glucose tolerance curves performed before and after specific hormone therapy indicates that with adequate treatment there is a marked increase in the threshold at which severe hypoglycemic symptoms occur. Thus the adequately treated patient with Addison's disease and the normal subject frequently do not manifest symptoms at a blood glucose level which may be associated with marked signs and symptoms of hypoglycemia in the untreated patient. The exact mechanism for this difference in threshold is not known at present. Its clinical significance, however, is apparent.

The increase in fasting blood glucose level which was observed following the administration of crystalline corticosterone and 17-hydroxy-11-dehydrocorticosterone precludes the inference that a rise in blood glucose following adrenal cortical hormone therapy is necessarily due to contaminating substances, viz., epinephrin.

The increased height to which the blood glucose level rose, and the glycosuria which was observed following specific hormone therapy in Patient E. L. (Figure 6), substantiate the studies of Lukens (16) and others regarding the nature of 
the diabetes in patients with adrenal cortical hyperfunction (tumor and hyperplasia).

Preliminary studies on lactic acid metabolism indicate that the ability of patients with Addison's disease to form glucose from this substance is greatly impaired. These studies have been confirmed experimentally in phlorhizinized rats and, in addition, it appears that the formation of glucose from pyruvate and from glycogenic amino acids is also impaired (14). Treatment with potent adrenal cortical hormone restores to normal the capacity of these animals to form glucose from lactic acid, pyruvate and glycogenic amino acids.

It is suggested that in adrenal cortical insufficiency carbohydrate oxidation is adequate, although the ability to form glucose and glycogen from intermediate products of carbohydrate and protein metabolism is impaired. As a result, the glycogen depots in the body are soon exhausted, and ingested preformed carbohydrate is required to maintain the blood glucose level and to provide a readily available source of energy. Hormone therapy increases the ability of the body to form glucose and glycogen from the intermediate products of both carbohydrate and protein metabolism and apparently increases the proportion of calories derived from protein and fat.

\section{SUMMARY}

Some or all of the following abnormalities in carbohydrate metabolism were observed in a large proportion of patients with Addison's disease:

1. A low-normal fasting blood glucose level.

2. Striking hypoglycemia :

(a) Following the oral or intravenous administration of glucose

(b) Following a 24-hour fast

(c) During fever or infections

(d) On a diet high in fat and low in carbohydrate.

3. Decreased threshold at which hypoglycemic symptoms appeared.

4. Flat type of oral glucose tolerance curve.

5. Absence of "rebound" in blood glucose curve following the administration of intravenous glucose.

6. Decreased glycemic response to epinephrin.
7. High standard respiratory quotient.

8. Increase over normal in respiratory quotient following glucose administration.

9. Low-normal basal metabolic rate.

With the exception of its effect on the oral glucose tolerance curve, the abnormalities in carbohydrate metabolism were not significantly altered by desoxycorticosterone acetate (Ciba) therapy. Treatment with large quantities of adrenal cortical extract (Wilson, $50 \mathrm{cc}$.), 17-hydroxy-11dehydrocorticosterone (Compound E, Kendall, 33 mgm.), and corticosterone ( $85 \mathrm{mgm}$.), in order of potency, was observed to

(a) Increase the fasting blood glucose level.

(b) Decrease the standard respiratory quotient.

(c) Increase the blood glucose level and renal excretion of nitrogen and decrease the respiratory quotient following the standard intravenous glucose tolerance test.

(d) Increase the threshold at which hypoglycemic symptoms appeared.

(e) Increase the basal metabolic rate.

Treatment with adrenal cortical extract was also observed to

(a) Increase the glycemic response to epinephrin.

(b) Increase the fasting blood glucose level during fever and infections.

These experiments suggest that the adrenal cortical hormone has a direct action on carbohydrate metabolism in man, and are in agreement with the animal experiments reported by Long, Katzin and Fry (5). Our experimental data suggest that the adrenal cortical hormone increases the ability of the organism to form glucose and glycogen from intermediate products of both carbohydrate and protein metabolism and in this manner regulates the utilization of carbohydrate.

\section{CONCLUSION}

A high proportion of untreated patients with Addison's disease was observed to have a disturbed carbohydrate metabolism. This defect could be most readily demonstrated by the application of a standard intravenous glucose tolerance test. The abnormality in carbohydrate metabolism appeared to be specific since it persisted de- 
spite the correction of the disturbance in electrolyte balance, plasma volume and blood pressure by means of desoxycorticosterone acetate therapy. Treatment with large quantities of adrenal cortical extract, 17-hydroxy-11-dehydrocorticosterone (Compound $\mathrm{E}$ ) and corticosterone, in order of potency, corrected the abnormal carbohydrate metabolism.

\section{PROTOCOL}

E. L. (Number 193336), a 51-year-old single business woman, was admitted to The Johns Hopkins Hospital on March 3, 1940, complaining of "weakness and sick stomach" for 6 months. She had first noticed loss of strength and weight in 1935 and since then had been troubled with spells of nausea. In November 1938 she had had an attack of bilateral bronchopneumonia, necessitating hospitalization for 18 days. Since then she had never recovered her strength. While in the hospital a nurse had commented on the darkness of her skin and she herself had noted increasing pigmentation of the gums, nipples, abdomen and hands. She also had experienced spells of hunger associated with nervousness and sweating which were relieved by food and she had developed the habit of eating fruit or milk between breakfast and lunch. On occasions it was necessary for her to stop on her way home from work late in the afternoon for a sandwich because of extreme hunger.

Her father had suffered from chronic bronchitis and had had an arrested pulmonary tuberculous lesion. She had had malaria in 1901, a partial thyroidectomy in 1914, and typhoid fever in 1919. In 1932 she had had an appendix drained and a subsequent repair of the incision. A cyst had been removed from the left breast in 1934 . During the past two years her menstrual periods had become irregular.

Physical examination on admission, March 3, 1940, revealed an undernourished middle-aged woman who appeared chronically ill. Her temperature was $99^{\circ} \mathrm{F}$., pulse rate 92 per minute, respirations 20 per minute and blood pressure $86 / 70 \mathrm{~mm}$. Hg. There was generalized dark brown pigmentation of the skin, most marked over the elbows, hands, knees and in the axillary folds. There were many small black freckles and the areolae were almost black in color. There was pigmentation of the gums and external genitalia. Some tortuosity of the retinal arteries was noted. The tonsils were small. There was a small amount of thyroid tissue palpable. The lungs were clear. The pulses were of poor volume. The heart was small and the sounds distant. The second pulmonic sound was reduplicated and louder than the aortic second sound. There were no cardiac murmurs. No abdominal organs or masses were felt. Pelvic and rectal examination revealed no abnormality. The neurological examination was normal.

The essential laboratory data were as follows:

Hemoglobin 80 per cent (12 grams), red blood cells 3.7 million, hematocrit 33 per cent cells, white blood cells
6,000 with polymorphonuclears 58 per cent, eosinophiles 4 per cent, monocytes 3 per cent and lymphocytes 35 per cent, the sedimentation rate $29 \mathrm{~mm}$. in one hour, corrected. The blood Wassermann was negative. The blood non-protein nitrogen was $32 \mathrm{mgm}$. per $100 \mathrm{cc}$. and the blood glucose $72 \mathrm{mgm}$. per $100 \mathrm{cc}$. On admission she was given intravenous hypertonic sodium chloride. The following morning the serum carbon dioxide combining power was 52.2 volume per cent. Chloride was 109.2 m.eq. per liter, sodium 139 m.eq. per liter and potassium 5.1 m.eq. per liter of serum.

The urine was found to have a specific gravity of 1.010 and no albumin or sugar. There were no formed elements. Cultures were negative for acid fast bacilli. A phenolsulfonphthalein test showed a dye excretion of 48 per cent in 2 hours.

$\mathrm{X}$-rays revealed fibroid infiltration at the left apex, no adrenal calcification and a normal sella turcica. The basal metabolic rate was minus 15 per cent. Gastric analysis showed no free hydrochloric acid until after histamine when it rose to $40^{\circ}$. The electrocardiogram was normal. Venous pressure was $95 \mathrm{~mm}$. of water. Circulation time with sodium cyanide was 18 seconds and with paraldehyde was 8 seconds. Tuberculin tests were negative at a dilution of 1 to 100,000 and 1 to 10,000. Carbohydrate studies are recorded in the text.

Course. During the first month in hospital this patient was maintained on supplementary sodium chloride therapy by mouth (10 grams) and frequent intravenous infusions of sodium chloride and glucose solution. On this regimen she was unable to be up and about for more than very brief periods. Her appetite was poor, her blood pressure $88 / 50 \mathrm{~mm}$. of $\mathrm{Hg}$, and her weight 44.0 $\mathrm{kgm}$. During her course of hospitalization she had one rather severe episode of vomiting and diarrhea, and in addition an urinary tract infection. During these periods she was given desoxycorticosterone acetate and adrenal cortical extract. With the subsidence of the infection the patient was started on a regimen of 5 grams of added sodium chloride by mouth and a single daily intramuscular injection of $4 \mathrm{mgm}$. of Percorten (desoxycorticosterone acetate in oil). On this regimen her strength improved, she gained $4 \mathrm{kgm}$. in weight and her blood pressure increased to a level of $130 / 85 \mathrm{~mm}$. of $\mathrm{Hg}$. On June 23, 1940, 8 pellets of crystalline desoxycorticosterone acetate (125 mgm. each) were implanted in the subcutaneous tissues of the left infrascapular region. The daily injections of Percorten were discontinued. The added sodium chloride therapy ( 5 grams daily) was maintained and the patient was discharged.

The authors wish to acknowledge the cooperation and assistance of Doctor Carlos Delbue and Miss Mildred Caldwell, and the technical assistance of Mr. Harry Eisenberg.

\section{BIBLIOGRAPHY}

1. Porges, O., Ueber Hypoglykämie bei Morbus Addison sowie bei nebennierenlosen Hunden. Ztschr. $f$. klin. Med., 1910, 69, 341. 
2. Eppinger, H., Falta, W., and Rudinger, C., Ueber die Wechselwirkung der Drüsen mit innerer Sekretion. Ztschr. f. klin. Med., Berlin, 1908, 66, 380.

3. Marañon, G., Action de L'insuline dans L'insuffisance Surrénale. Presse Méd., 1925, 33, 1665.

4. Levy Simpson, S., Addison's disease and its treatment by cortical extract. Quart. J. Med., 1932, 1, 99.

5. Long, C. N. H., Katzin, B., and Fry, E. G., The adrenal cortex and carbohydrate metabolism. Endocrinology, 1940, 26, 309.

6. Lusk, G., Animal calorimetry ; analysis of the oxidation of mixtures of carbohydrate and fat. A correction. J. Biol. Chem., 1924, 59, 41.

7. Folin, O., and Malmros, H., An improved form of Folin's micro method for blood sugar determinations. J. Biol. Chem., 1929, 83, 115.

8. Richter, C. P., and Eckert, J. F., Mineral metabolism of adrenalectomized rats studied by the appetite method. Endocrinology, 1938, 22, 214.

9. Thorn, G. W., Howard, R. P., and Emerson, K., Jr., Treatment of Addison's disease with desoxycorticosterone acetate, a synthetic adrenal cortical hormone (preliminary report). J. Clin. Invest., 1939, 18, 449.
10. Ferrebee, J. W., Ragan, C., Atchley, D. W., and Loeb, R. F., Desoxycorticosterone esters; certain effects in the treatment of Addison's disease. J. A. M. A., 1939, 113, 1725.

11. Rowntree, L. G., and Snell, A. M., A Clinical Study of Addison's Disease. W. B. Saunders Company, Philadelphia, 1931.

12. Thorn, G. W., and Firor, W. M., Desoxycorticosterone acetate therapy in Addison's disease: Clinical considerations. J. A. M. A., 1940, 114, 2517.

13. Kendall, E. C., Flock, E. V., Bollman, J. L., and Mann, F. C., The influence of cortin and sodium chloride on carbohydrate and mineral metabolism in adrenalectomized dogs. J. Biol. Chem., 1938, 126, 697.

14. Lewis, R. A., Kuhlmann, D., Delbue, C. A., Koepf, G. F., and Thorn, G. W., Adrenal cortex and carbohydrate metabolism. Endocrinology. (In press.)

15. Thorn, G. W., Engel, L. L., and Eisenberg, H., The effect of corticosterone and related compounds on the renal excretion of electrolytes. J. Exper. Med., 1938, 68, 161.

16. Lukens, F. D. W., and Palmer, H. D., Adrenal cortical virilism. Endocrinology, 1940, 26, 941. 